\title{
Synthesis and Structural Characterization of Configurational Isomers of Tungsten-Palladium Complexes with Bridging Diphenyl(dithioalkoxycarbonyl)phosphine as a Ligand and Phosphine Transfer from Tungsten to Palladium
}

\author{
Kuang-Hway Yih,*,† Gene-Hsiang Lee, ${ }^{*}$ and Yu Wang ${ }^{\ddagger}$ \\ Department of Applied Cosmetology, Hung Kuang Institute of Technology, Sahlu, Taichung, \\ Taiwan 433, Republic of China, and Department of Chemistry, National Taiwan University, \\ Taiwan 106, Republic of China
}

Received April 23, 1999

\begin{abstract}
Treatment of the complex $\left[\mathrm{W}(\mathrm{CO})_{5}\left[\mathrm{PPh}_{2}\left(\mathrm{CS}_{2} \mathrm{Me}\right)\right]\right]$ (2) with $\left[\mathrm{Pd}\left(\mathrm{PPh}_{3}\right)_{4}\right](\mathbf{1})$ affords binuclear complexes such as anti-[( $\left.\left.\mathrm{Ph}_{3} \mathrm{P}\right)_{2} \mathrm{Pd}\left[\mu-\eta^{1}, \eta^{2}-\left(\mathrm{CS}_{2} \mathrm{Me}\right) \mathrm{PPh}_{2}\right] \mathrm{W}(\mathrm{CO})_{5}\right](\mathbf{3})$, syn- $\left[\left(\mathrm{Ph}_{3} \mathrm{P}\right)_{2} \mathrm{Pd}\left[\mu-\eta^{1}, \eta^{2}-\left(\mathrm{CS}_{2} \mathrm{Me}\right) \mathrm{PPh}_{2}\right] \mathrm{W}(\mathrm{CO})_{5}\right](\mathbf{4})$, and trans[W(CO) $\left.{ }_{4}\left(\mathrm{PPh}_{3}\right)_{2}\right](\mathbf{5})$. In 3 and $\mathbf{4}$, respectively, the $\mathrm{W}$ and $\mathrm{Pd}$ atoms are in anti and syn configurations with respect to the $\mathrm{P}-\mathrm{CS}_{2}$ bond of the diphenyl(dithiomethoxycarbonyl)phosphine ligand, $\mathrm{PPh}_{2}\left(\mathrm{CS}_{2} \mathrm{Me}\right)$. Complex 3 undergoes extensive rearrangement in $\mathrm{CHCl}_{3}$ at room temperature by transfer of a $\mathrm{PPh}_{3}$ ligand from $\mathrm{Pd}$ to $\mathrm{W}$, eliminating $\left[\mathrm{W}(\mathrm{CO})_{5}\left(\mathrm{PPh}_{3}\right)\right](7)$, while the $\mathrm{PPh}_{2} \mathrm{CS}_{2} \mathrm{Me}$ ligand transfers from $\mathrm{W}$ to $\mathrm{Pd}$ to give $\left[\left[\left(\mathrm{Ph}_{3} \mathrm{P}\right) \mathrm{Pd}\left[\mu-\eta^{1}, \eta^{2}-\left(\mathrm{CS}_{2} \mathrm{Me}\right)-\right.\right.\right.$ $\left.\left.\left.\mathrm{PPh}_{2}\right]\right]_{2}\right]$ (6). In complex 6, the $\left[\mathrm{Pd}\left(\mathrm{PPh}_{3}\right)\right]$ fragments are held together by two bridging $\mathrm{PPh}_{2}\left(\mathrm{CS}_{2} \mathrm{Me}\right)$ ligands. Each $\mathrm{PPh}_{2}\left(\mathrm{CS}_{2} \mathrm{Me}\right)$ ligand is $\pi$-bonded to one $\mathrm{Pd}$ atom through the $\mathrm{C}=\mathrm{S}$ linkage and $\sigma$-bonded to the other $\mathrm{Pd}$ through the phosphorus atom, resulting in a six-membered ring. Treatment of $\mathrm{Pd}\left(\mathrm{PPh}_{3}\right)_{4}$ with $\left[\mathrm{W}(\mathrm{CO})_{5}\left[\mathrm{PPh}_{2^{-}}\right.\right.$ $\left.\left.\left[\mathrm{CS}_{2}\left(\mathrm{CH}_{2}\right)_{n} \mathrm{CN}\right]\right]\right](n=1, \mathbf{8 a} ; n=2, \mathbf{8 b})$ in $\mathrm{CH}_{2} \mathrm{Cl}_{2}$ affords syn- $\left[\left(\mathrm{Ph}_{3} \mathrm{P}\right)_{2} \mathrm{Pd}\left[\mu-\eta^{1}, \eta^{2}-\left[\mathrm{CS}_{2}\left(\mathrm{CH}_{2}\right)_{n} \mathrm{CN}\right] \mathrm{PPh}_{2}\right] \mathrm{W}-\right.$ $\left.(\mathrm{CO})_{5}\right](n=1,9 \mathbf{9} ; n=2,9 \mathbf{b})$. Similar configurational products $\operatorname{syn}-\left[\left(\mathrm{Ph}_{3} \mathrm{P}\right)_{2} \mathrm{Pd}\left[\mu-\eta \eta^{1}, \eta^{2}-\left(\mathrm{CS}_{2} \mathrm{R}\right) \mathrm{PPh}_{2}\right] \mathrm{W}(\mathrm{CO})_{5}\right](\mathrm{R}$ $\left.=\mathrm{C}_{2} \mathrm{H}_{5}, \mathrm{C}_{3} \mathrm{H}_{5}, \mathrm{C}_{2} \mathrm{H}_{4} \mathrm{OH}, \mathrm{C}_{3} \mathrm{H}_{6} \mathrm{CN}, \mathbf{1 1 a}-\mathbf{d}\right)$ are synthesized by the reaction of $\mathrm{Pd}\left(\mathrm{PPh}_{3}\right)_{4}$ with $\left[\mathrm{W}(\mathrm{CO})_{5}\left[\mathrm{PPh}_{2^{-}}\right.\right.$ $\left.\left.\left(\mathrm{CS}_{2} \mathrm{R}\right)\right]\right]\left(\mathrm{R}=\mathrm{C}_{2} \mathrm{H}_{5}, \mathrm{C}_{3} \mathrm{H}_{5}, \mathrm{C}_{2} \mathrm{H}_{4} \mathrm{OH}, \mathrm{C}_{3} \mathrm{H}_{6} \mathrm{CN}, \mathbf{1 0 a}-\mathbf{d}\right)$. Although complexes 11a-d have the same configuration as 9a,b, the SR group is oriented away from Pd in the former and near Pd in the latter. In these complexes, the diphenyl(dithioalkoxycarbonyl)phosphine ligand is bound to the two metals through the $\mathrm{C}=\mathrm{S} \pi$-bonding and to phosphorus through the $\sigma$-bonding. All of the complexes are identified by spectroscopic methods, and the structures of complexes 3, 6, 9a, and 11d are determined by single-crystal X-ray diffraction. Complexes 3, 9, and 11d crystallize in the triclinic space group $P \overline{1}$ with $Z=2$, whereas $\mathbf{6}$ belongs to the monoclinic space group $P 2 / c$ with $Z=4$. The cell dimensions are as follows: for $3, a=10.920(3) \AA, b=14.707(5) \AA, c=16.654(5) \AA, \alpha=$ 99.98(3) ${ }^{\circ}, \beta=93.75(3)^{\circ}, \gamma=99.44(3)^{\circ}$; for $\mathbf{6}, a=15.106(3) \AA, b=9.848(3) \AA, c=20.528(4) \AA, \beta=104.85$ (2) $)^{\circ}$; for $9 \mathrm{a}, a=11.125(3) \AA, b=14.089(4) \AA, c=17.947(7) \AA, \alpha=80.13(3)^{\circ}, \beta=80.39(3)^{\circ}, \gamma=89.76(2)^{\circ}$; for 11d, $a=11.692(3) \AA, b=13.602(9) \AA, c=18.471(10) \AA, \alpha=81.29(5)^{\circ}, \beta=80.88(3)^{\circ}, \gamma=88.82(1)^{\circ}$.
\end{abstract}

\section{Introduction}

Since the first $\mathrm{CS}_{2}$ metal complex $\left[\mathrm{Ni}_{2}\left(\mathrm{CS}_{2}\right)_{2}\left(\mathrm{PPh}_{3}\right)_{2}\right]$ was prepared by Baird and Wilkinson ${ }^{1}$ in 1967, transition metal$\mathrm{CS}_{2}$ complexes have attracted considerable attention. Carbon disulfide, $\mathrm{CS}_{2}$, has proved to be a versatile ligand, being capable of coordinating to one $\mathrm{e}^{2-11}$ or more ${ }^{12-14}$ metals and it showing

\footnotetext{
$\dagger$ Huang Kuang Institute of Technology.

National Taiwan University.

(1) Baird, M. C.; Wilkinson, G. J. Chem. Soc. A 1967, 865.

(2) Kashiwagi, T.; Yasuoka, N.; Ueki, T.; Kasai, N.; Kakudo, M.; Takahashi, S.; Hagihara, N. Bull. Chem. Soc. Jpn. 1968, 296.

(3) Clark, G. R.; Collins, T. J.; James, S. M.; Roper, W. R. J. Organomet. Chem. 1977, 125, C23.

(4) Werner, H.; Leonhard, K.; Burschka, C. J. Organomet. Chem. 1978, 160, 291.

(5) Bozec, H. L.; Dixneuf, P. H.; Carty, A. J.; Taylor, N. J. Inorg. Chem. 1978, 17, 2568 .

(6) Fachinetti, G.; Floriani, C.; Chiesi-Villa, A.; Guastini, C. J. Chem. Soc., Dalton Trans. 1979, 1612.

(7) Werner, H. Coord. Chem. Rev. 1982, 43, 165.

(8) Mason, M. G.; Swepston, P. N.; Ibers, J. A. Inorg. Chem. 1983, 22 , 411.

(9) Bianchini, C.; Ghilardi, C. A.; Meli, A.; Orlandini, A. J. Organomet. Chem. 1984, 270, 251.
}

a variety of insertion ${ }^{15,16}$ and disproportionation ${ }^{17}$ reactions. Moreover, $\mathrm{CS}_{2}$-containing metal complexes can be used as models for $\mathrm{CO}_{2}$ complexes, which are much more difficult to investigate. ${ }^{18,19}$ Consequently, three $\mathrm{CS}_{2}$ derivatives, $\mathrm{R}_{3} \mathrm{P}^{+} \mathrm{CS}_{2}{ }^{-}$, $\mathrm{R}_{2} \mathrm{PCS}_{2}{ }^{-}$, and $\mathrm{R}_{2} \mathrm{NCS}_{2}{ }^{-}$, were synthesized to understand variable coordination chemistry.

(10) Ibers, J. A. Chem. Soc. Rev. 1982, 11, 57.

(11) Bianchini, C.; Mealli, C.; Meli, A.; Sabat, M.; Silvestre, J.; Hoffmann, R. Organometallics 1986, 5, 1733.

(12) Southern, T. G.; Oehmichen, U.; Le Marouille, J. Y.; Le Bozec, H.; Grandjean, D.; Dixneuf, P. H. Inorg. Chem. 1980, 19, 2976.

(13) Bianchini, C.; Mealli, C.; Meli, A.; Orlandini, A.; Sacconi, L. Inorg. Chem. 1980, 19, 2968.

(14) Brennan, J. G.; Andersen, R. A.; Zalkin, A. Inorg. Chem. 1986, 25 1756.

(15) Rossi, R.; Marchi, A.; Duatti, A.; Magon, L. J. Chem. Soc., Dalton Trans. 1988, 899.

(16) Yih, K. H.; Chen, S. C.; Lin, Y. C.; Cheng, M. C.; Wang, Y. J. Organomet. Chem. 1995, 494, 149.

(17) Butler, I. S.; Fenster, A. E. J. Organomet. Chem. 1974, 66, 161.

(18) Lisy, J. M.; Dobrzynski, E. D.; Angelici, R. J.; Clardy, J. J. Am. Chem. Soc. 1975, 97, 656 .

(19) Herberhold, M.; Suss-Fink, M.; Kreiter, C. G. Angew. Chem., Int. Ed. Engl. 1977, 16, 193. 


\section{Scheme 1}

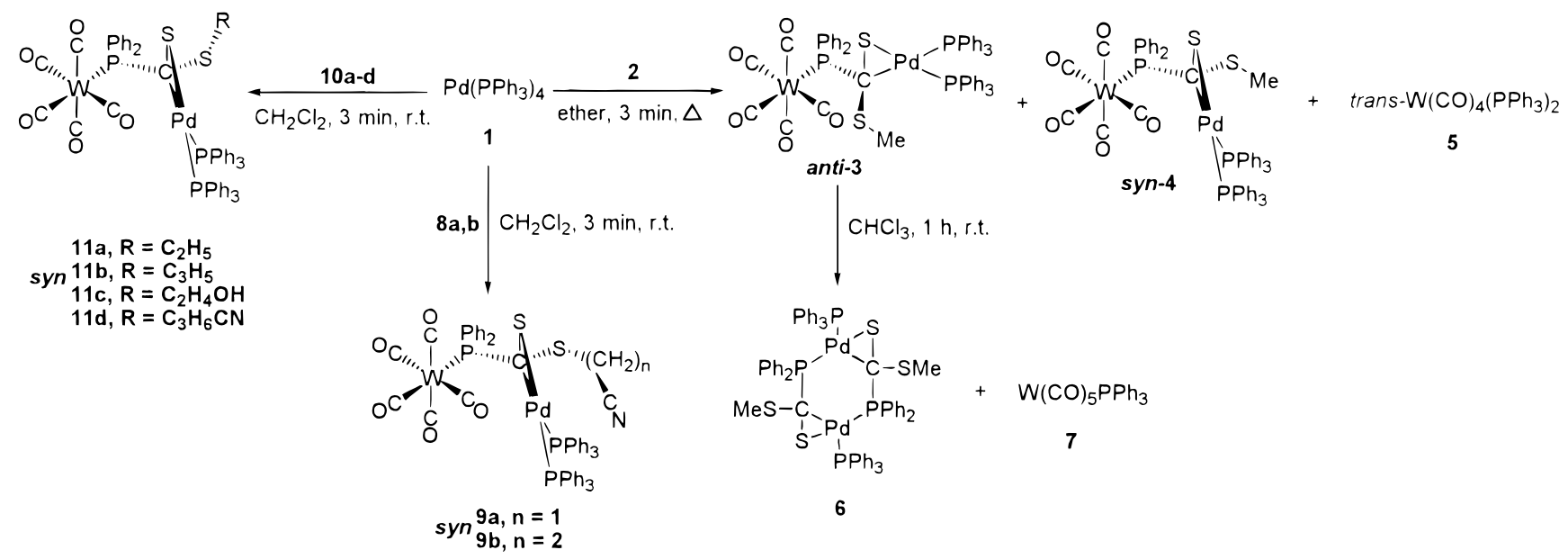

2: $\mathrm{W}(\mathrm{CO})_{5}\left(\mathrm{PPh}_{2} \mathrm{CS}_{2} \mathrm{Me}\right)$

8: $\mathrm{W}(\mathrm{CO})_{5}\left[\mathrm{PPh}_{2} \mathrm{CS}_{2}\left(\mathrm{CH}_{2}\right)_{n} \mathrm{CN}\right](\mathbf{a}, \mathrm{n}=1 ; \mathbf{b}, \mathrm{n}=2)$

10: $W(C O)_{5}\left(P^{2} h_{2} C S_{2} R\right)\left(a, R=C_{2} H_{5} ; b, R=C_{3} H_{5} ; c, R=C_{2} H_{4} O H ; d, R=C_{3} H_{6} C N\right)$

A typical example, the zwitterionic $\mathrm{R}_{3} \mathrm{P}^{+} \mathrm{CS}_{2}{ }^{-}{ }^{20-25}$ ligand, has various bonding modes, which include monodentate coordination through one $\mathrm{S}$ atom, ${ }^{20}$ chelation ${ }^{21}$ or bridging ${ }^{22}$ through two $\mathrm{S}$ atoms, and dinuclear pesudoallylic bridging forms, i.e., an $\eta^{3}, \sigma$ mode with donation of six electrons ${ }^{22-24}$ and an $\eta^{2}, \eta^{3}$ mode with donation of eight electrons. ${ }^{25}$ The anionic ligands $\mathrm{R}_{2} \mathrm{PCS}_{2}{ }^{-}$and $\mathrm{R}_{2} \mathrm{NCS}_{2}{ }^{-26,27}$ normally show monodentate coordination through $\mathrm{P}$ or $\mathrm{S}$ and bidentate coordination through $\mathrm{P}$ and $\mathrm{S}$ and through $\mathrm{N}$ and $\mathrm{S}$, respectively. Little effort has been directed toward investigating the reactivity of the ligand $\mathrm{R}_{2} \mathrm{PCS}_{2}{ }^{-}$and its derivative $\mathrm{R}_{2} \mathrm{PCS}_{2} \mathrm{R}$. To date, the neutral alkyl (diorganothiophosphinoyl)dithioformate compound, $\mathrm{R}_{2} \mathrm{P}(\mathrm{S}) \mathrm{C}$ ( $\mathrm{S}) \mathrm{R}$, is the only analogous example that has been used to react with $\left[\mathrm{Pt}\left(\mathrm{PPh}_{3}\right)_{2} \mathrm{C}_{2} \mathrm{H}_{4}\right]$, forming the $\mathrm{C}=\mathrm{S} \pi$-coordination complex. ${ }^{28}$ Notably, in metal complexes containing the abovementioned ligands, no phosphine transfer reactions or configurational isomers have been observed.

Recently, we developed an efficient method to synthesize metal complexes with the diphenyl(dithioalkoxycarbonyl)phosphine ligand, $\mathrm{Ph}_{2} \mathrm{P}\left(\mathrm{CS}_{2} \mathrm{R}\right),{ }^{29}$ which allows more extensive exploration of the chemistry of these complexes. In a previous communication, ${ }^{30}$ we reported the $\mathrm{Ph}_{2} \mathrm{P}\left(\mathrm{CS}_{2} \mathrm{Me}\right)$ ligand transfer reaction between $\left[\mathrm{Pd}\left(\mathrm{PPh}_{3}\right)_{4}\right](\mathbf{1})$ and $\left[\mathrm{W}(\mathrm{CO})_{5}\left[\mathrm{PPh}_{2}\left(\mathrm{CS}_{2} \mathrm{Me}\right)\right]\right]$ (2), forming anti-[( $\left.\left.\mathrm{Ph}_{3} \mathrm{P}\right)_{2} \mathrm{Pd}\left[\mu-\eta^{1}, \eta^{2}-\left(\mathrm{CS}_{2} \mathrm{Me}\right) \mathrm{PPh}_{2}\right] \mathrm{W}(\mathrm{CO})_{5}\right](3)$ as an intermediate.

(20) Bianchini, C.; Meli, A.; Orlandini, A. Inorg. Chem. 1982, 21, 4161.

(21) George, R. C.; Terrence, J. C.; Suzanne, M. J.; Warren, R. R.; Keith, G. T. Chem. Commun. 1976, 475.

(22) Alvarez, B.; Miguel, D.; Riera, V. Organometallics 1991, 10, 384.

(23) Kreissl, F. R.; Ullrich, N.; Wirsing, A.; Thewalt, U. Organometallics $1991,10,3275$

(24) Galindo, A.; Gutierrez-Puebla, E.; Monge, A.; Munoz, M. A.; Pastor, A.; Ruiz, C.; Carmona, E. J. Chem. Soc., Dalton Trans. 1992, 2307.

(25) Miguel, D.; Perez-Martinez, J. A.; Riera, V. Organometallics 1993 12,1394

(26) Kunze, U.; Jawad, H.; Burghardt, R.; Tittmann, R.; Kruppa, V. J. Organomet. Chem. 1986, 302, C30.

(27) Ambrosius, H. P. M. M.; Van Hemert, A. W.; Bosman, W. P.; Hoordik, J. H.; Ariaans, G. J. A. Inorg. Chem. 1984, 23, 2678-2685.

(28) Carr, W. S.; Colton, R.; Dakternieks, D. Inorg. Chem. 1984, 23, 720.

(29) Yih, K.-H.; Lin, Y.-C.; Cheng, M.-C.; Wang, Y. J. Chem. Soc., Dalton Trans. 1995, 1305

(30) Yih, K.-H.; Lin, Y.-C.; Cheng, M.-C.; Wang, Y. J. Organomet. Chem. 1994, 474, C34
On the basis of these experimental results, we investigated the existence of configurational isomers in complexes between [diphenyl(dithioalkoxycarbonyl)phosphine]tungsten(0) compounds and $\mathrm{Pd}\left(\mathrm{PPh}_{3}\right)_{4}$. We report our results in this article, along with four X-ray crystal structure analyses that were carried out to provide accurate structural parameters.

\section{Results and Discussion}

Reaction of $\left[\mathrm{Pd}\left(\mathrm{PPh}_{3}\right)_{4}\right](1)$ with $\left[\mathrm{W}(\mathrm{CO})_{5}\left[\mathrm{PPh}_{2}\left(\mathrm{CS}_{2} \mathrm{Me}\right)\right]\right]$ (2). The reaction of $\left[\mathrm{Pd}\left(\mathrm{PPh}_{3}\right)_{4}\right](\mathbf{1})$ and $\left[\mathrm{W}(\mathrm{CO})_{5}\left[\mathrm{PPh}_{2}\left(\mathrm{CS}_{2-}\right.\right.\right.$ $\mathrm{Me})$ ]] (2) in refluxing diethyl ether affords a yellow crystalline product, identified as anti- $\left[\left(\mathrm{Ph}_{3} \mathrm{P}\right)_{2} \mathrm{Pd}\left[\mu-\eta^{1}, \eta^{2}-\left(\mathrm{CS}_{2} \mathrm{Me}\right) \mathrm{PPh}_{2}\right] \mathrm{W}\right.$ $(\mathrm{CO})_{5}$ ] (3) (Scheme 1), in $55 \%$ yield. Compound $\mathbf{3}$ is moderately soluble in dichloromethane and acetonitrile, slightly soluble in diethyl ether and tetrahydrofuran, and insoluble in $n$-hexane.

The spectroscopic and analytical data of $\mathbf{3}$ are in agreement with the formulation. The FAB mass spectrum of $\mathbf{3}$ exhibits a base peak corresponding to its molecular mass. In the IR spectrum of 3, three terminal carbonyl stretching bands at 2060 (m), 1914 (vs), and 1887 (s) $\mathrm{cm}^{-1}$ are observed, which is a typical pattern for an $\mathrm{LM}(\mathrm{CO})_{5}$ unit in octahedral geometry. The ${ }^{1} \mathrm{H}$ NMR spectrum of $\mathbf{3}$ exhibits a resonance at $\delta 2.09$ assignable to the methyl protons of the $\mathrm{PPh}_{2}\left(\mathrm{CS}_{2} \mathrm{Me}\right)$ ligand, and the corresponding ${ }^{13} \mathrm{C}\left\{{ }^{1} \mathrm{H}\right\}$ NMR signal appears at $\delta 18.7$. In the ${ }^{13} \mathrm{C}\left\{{ }^{1} \mathrm{H}\right\}$ NMR spectrum of $\mathbf{3}$, three resonances appear in the carbonyl region. The two resonances at $\delta 214.9$ and 198.8 with a ratio of $1 / 4$ are attributed to the trans and cis carbonyl groups, respectively. The resonance at $\delta 208.2$ is assigned to the carbon atom of $\mathrm{CS}_{2}$ in the $\mathrm{PPh}_{2}\left(\mathrm{CS}_{2} \mathrm{Me}\right)$ ligand. In the ${ }^{31} \mathrm{P}$ $\left\{{ }^{1} \mathrm{H}\right\}$ NMR spectrum of $\mathbf{3}$, a resonance at $\delta 51.6$ with a tungsten satellite $\left({ }^{1} J_{\mathrm{W}-\mathrm{P}}=257.6 \mathrm{~Hz}\right)$ and two broad resonances at $\delta$ 22.2 and 22.4 indicate $\mathrm{P}$-coordination of the $\mathrm{PPh}_{2}\left(\mathrm{CS}_{2} \mathrm{Me}\right)$ ligand to $\mathrm{W}$ and of the two triphenylphosphine ligands to $\mathrm{Pd}$ in the cis geometry.

To confirm the bonding mode of the $\mathrm{PPh}_{2}\left(\mathrm{CS}_{2} \mathrm{Me}\right)$ ligand, complex 3 was characterized by an X-ray diffraction analysis. Its ORTEP diagram with atom labeling is shown in Figure 1. Table 2 contains selected bond distances and angles. The most remarkable features of the whole structure are the $\pi$-bonding of the $\mathrm{C}=\mathrm{S}$ moiety in the $\mathrm{PPh}_{2}\left(\mathrm{CS}_{2} \mathrm{Me}\right)$ ligand to the $\mathrm{Pd}$ atom 


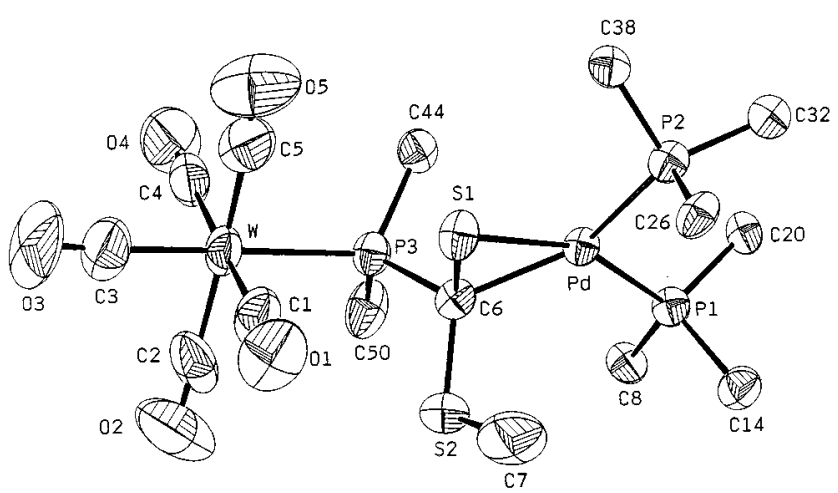

Figure 1. ORTEP plot of the molecular structure of compound 3. The phenyl groups are omitted for clarity.

and the $\sigma$-bonding to the $\mathrm{W}$ atom through the phosphorus atom. Notably, the two metal atoms are on two different sides with respect to the $\mathrm{P}-\mathrm{CS}_{2}$ bond of the $\mathrm{PPh}_{2}\left(\mathrm{CS}_{2} \mathrm{Me}\right)$ ligand. The $\mathrm{Pd}$ atom and its neighboring atoms, $\mathrm{P}(1), \mathrm{P}(2), \mathrm{S}(1)$, and $\mathrm{C}(6)$, lie in a distorted square plane, the distortion being mainly due to the short bite of the $\mathrm{C}=\mathrm{S}$ linkage $\left[\mathrm{C}-\mathrm{Pd}-\mathrm{S}=46.09(21)^{\circ}\right]$. The W-Pd bond distance in 3, 5.620(2) $\AA$, indicates that there is no bonding interaction between the two metal atoms. The sulfur-carbon bond lengths in the $\mathrm{PPh}_{2}\left(\mathrm{CS}_{2} \mathrm{Me}\right)$ ligand range from $1.736(8)$ to $1.794(8) \AA$. Compared with the typical $\mathrm{S}-\mathrm{C}$ single- and double-bond lengths of 1.81 and $1.71 \AA$, these parameters are indicative of delocalized bonding for the four atoms $\mathrm{S}(1), \mathrm{C}(6), \mathrm{S}(2)$, and $\mathrm{C}(7)$. Moreover, the $\mathrm{C}(6)-\mathrm{S}(1)$ bond distance of 1.736(8) $\AA$ is longer than the corresponding carbonsulfur bond distances observed in $\eta^{2}-\mathrm{CS}_{2}\left(\mathrm{sp}^{2}\right)$ transition metal complexes $\left[1.65(3) \AA\right.$ in $\left[\left(\mathrm{PPh}_{3}\right)_{2} \mathrm{Pd}\left(\eta^{2}-\mathrm{CS}_{2}\right)\right],{ }^{2} 1.66 \AA$ in $\left[\left(\mathrm{PPh}_{3}\right)_{2} \mathrm{Ru}\left(\eta^{2}-\mathrm{CS}_{2} \mathrm{Me}\right)(\mathrm{CO})_{2}\right]\left[\mathrm{ClO}_{4}\right],{ }^{3} 1.68(1) \AA$ in $[\mathrm{CpCo}-$ $\left.\left(\mathrm{PMe}_{3}\right)\left(\eta^{2}-\mathrm{CS}_{2}\right)\right],{ }^{4} 1.676(7) \AA$ in $\left[\mathrm{Fe}\left(\mathrm{PPh}_{3}\right)\left(\mathrm{PMe}_{3}\right)(\mathrm{CO})_{2}\left(\eta^{2}-\right.\right.$ $\left.\left.\mathrm{CS}_{2}\right)\right],{ }^{5} 1.667(4) \AA$ in $\left[(\mathrm{Cp})_{2} \mathrm{~V}\left(\eta^{2}-\mathrm{CS}_{2}\right)\right],{ }^{6} 1.68(1) \AA$ in [(triphos)$\left.\mathrm{Co}\left(\eta^{2}-\mathrm{CS}_{2}\right)\right],{ }^{12} 1.658(6) \AA$ in $\left[\left(\mathrm{PhMe}_{2} \mathrm{P}\right)_{2}(\mathrm{CO})_{2} \mathrm{FeCS}_{2} \mathrm{Mn}-\right.$ $\left.(\mathrm{CO})_{2} \mathrm{Cp}\right],{ }^{13} 1.63(1) \AA$ in $\left[\left(\mathrm{PPh}_{3}\right) \mathrm{Ni}\left(\mu-\mathrm{CS}_{2}\right)_{2} \mathrm{Ni}\left(\mathrm{PPh}_{3}\right)\right],{ }^{31}$ and 1.674(6) $\AA$ in $\left.\left[\left(\mathrm{PPh}_{3}\right) \mathrm{Pt}\left(\mu-\mathrm{CS}_{2}\right)_{2} \mathrm{Pt}\left(\mathrm{PPh}_{3}\right)\right]^{32}\right]$. The $\mathrm{C}-\mathrm{S}$ bond lengths are longer than those in free $\mathrm{CS}_{2}(1.554 \AA)$, indicating coordination of $\mathrm{CS}_{2}$ in an $\eta^{2}$ fashion, which reduces the bond order of the $\mathrm{C}=\mathrm{S}$ bonds. A comment must be made about the carbon atom of the $\mathrm{CS}_{2}$ group. An examination of its bond distances and angles shows a geometrical environment characteristic of an $\mathrm{sp}^{3}$ hybridization. The $\mathrm{Pd}-\mathrm{C}(6)-\mathrm{S}(1)$ angle, 71.0$(3)^{\circ}$, is significantly different from the others, which are in the range $107.0(5)-124.1(4)^{\circ}$.

For the $\mathrm{PPh}_{3}$ ligands, the average values of $\angle \mathrm{C}-\mathrm{P}-\mathrm{C}^{\prime} \mathrm{S}$ and $\angle \mathrm{Pd}-\mathrm{P}-\mathrm{C}^{\prime} \mathrm{S}$ are 103 and $115^{\circ}$, respectively, and the geometry around the $\mathrm{P}$ atom is distorted tetrahedral. The $\mathrm{Pd}-\mathrm{P}(1)$ distance in 3, 2.317(2) $\AA$, is considerably shorter than the sum of covalent radii $(2.42 \AA)$. This value is similar to those in $\left[\left(\mathrm{C}_{4} \mathrm{H}_{7}\right) \mathrm{PdPPh}_{3}\right]$ $(2.31 \AA)$ and $\left[\left(\mathrm{PPh}_{3}\right)_{2} \mathrm{Pd}\left(\eta^{2}-\mathrm{CS}_{2}\right)\right](2.316(8) \AA)$. The $\mathrm{Pd}-\mathrm{S}(1)$ distance, 2.278(2) $\AA$, is within the normal $\mathrm{Pd}-\mathrm{S}$ length range (2.23-2.31 $\AA$ ). ${ }^{5}$ The $\mathrm{Pd}-\mathrm{C}(6)$ bond length, $2.145(8) \AA$, is also within the usual range for $\mathrm{Pd}-\mathrm{C}\left(\mathrm{sp}^{3}\right) \sigma$ bonds. No bonding interaction between the palladium and the phenyl carbon atoms is apparent.

The singularity of the diphenyl(dithiomethoxycarbonyl)phosphine complex $\mathbf{3}$ does not allow a direct comparison with any other compounds reported in the literature. However, 3 shows some structural analogies with the complex $\left[\mathrm{Ph}_{2} \mathrm{PCH}_{2}-\right.$

(31) Bianchini, C.; Ghilardi, C. A.; Meli, A.; Midollini, S.; Orlandini, A. J. Chem. Soc., Chem. Commun. 1983, 753.

(32) Farrar, D. H.; Gukathasan, R. R.; Morris, S. A. Inorg. Chem. 1984, 23,3258
$\left.\mathrm{CH}_{2} \mathrm{~N}\left(\mathrm{CH}_{2} \mathrm{CH}_{2} \mathrm{PPh}_{2}\right)_{2} \mathrm{Ni}\left(\mathrm{CS}_{2} \mathrm{Me}\right)\right]\left[\mathrm{BPh}_{4}\right] .{ }^{9}$ In this compound, the nickel atom is coordinated in an $\eta^{2}$ fashion by the $\mathrm{C}=\mathrm{S}$ moiety and the carbon in the thiocarbonyl shows an $\mathrm{sp}^{3}$ hybridization character, albeit the nickel complex is mononuclear, unlike the binuclear complex $\mathbf{3}$, in which the two metals are bridged by $\mathrm{PPh}_{2} \mathrm{CS}_{2} \mathrm{Me}$ ligand.

The reaction of $\mathbf{1}$ and $\mathbf{2}$ yields not only complex $\mathbf{3}$ but also small amounts of complexes syn- $\left[\left(\mathrm{Ph}_{3} \mathrm{P}\right)_{2} \mathrm{Pd}\left[\mu-\eta^{1}, \eta^{2}-\left(\mathrm{CS}_{2} \mathrm{Me}\right)-\right.\right.$ $\left.\left.\mathrm{PPh}_{2}\right] \mathrm{W}(\mathrm{CO})_{5}\right]$ (4) (10\%) and trans-[W(CO) $\left.\left(\mathrm{PPh}_{3}\right)_{2}\right](5)(20 \%)$ (Scheme 1). Although complex 4 is too unstable for its ${ }^{13} \mathrm{C}$ $\left\{{ }^{1} \mathrm{H}\right\}$ NMR spectrum to be obtained, its mass spectrum is the same as that of complex 3. Interestingly, complex $\mathbf{4}$ exhibits an ${ }^{31} \mathrm{P}\left\{{ }^{1} \mathrm{H}\right\}$ NMR pattern significantly different from that of complex 3. The ${ }^{31} \mathrm{P}\left\{{ }^{1} \mathrm{H}\right\}$ NMR spectrum of $\mathbf{4}$ displays a resonance at $\delta 28.8$ with a tungsten satellite $\left({ }^{1} J_{\mathrm{W}-\mathrm{P}}=204.5\right.$ $\mathrm{Hz},{ }^{3} J_{\mathrm{P}-\mathrm{P}}=7.0 \mathrm{~Hz}$ ) which is coupled with a resonance of one of the $\mathrm{PPh}_{3}$ ligands on $\mathrm{Pd}$. Two other peaks resonating at $\delta$ $21.7\left(\mathrm{~d},{ }^{2} J_{\mathrm{P}-\mathrm{P}}=39.1 \mathrm{~Hz}\right)$ and $\delta 25.2\left(\mathrm{dd},{ }^{3} J_{\mathrm{P}-\mathrm{P}}=7.0 \mathrm{~Hz},{ }^{2} J_{\mathrm{P}-\mathrm{P}}\right.$ $=39.1 \mathrm{~Hz}$ ) with low coupling constants are in favor of a cis geometry for the phosphines on $\mathrm{Pd}$. In complex 3 , the $\mathrm{PPh}_{2}\left(\mathrm{CS}_{2^{-}}\right.$ $\mathrm{Me}$ ) ligand on $\mathrm{W}$ does not couple with $\mathrm{a} \mathrm{PPh}_{3}$ on $\mathrm{Pd}$, but in complex $\mathbf{4}$, such coupling does occur. Clearly, complexes $\mathbf{3}$ and 4 possess the same molecular weight but differ in their configurations. This is possibly due to different coordinations of the thiocarbonyl group of $\left[\mathrm{W}(\mathrm{CO})_{5}\left[\mathrm{PPh}_{2}\left(\mathrm{CS}_{2} \mathrm{Me}\right)\right]\right]$ (2) with $\left[\mathrm{Pd}\left(\mathrm{PPh}_{3}\right)_{4}\right]$. The thiocarbonyl group may coordinate with the Pd fragment in two ways: one is to form the anti configurational complex by occupying the two metal atoms on opposite sides of the $\mathrm{P}-\mathrm{CS}_{2} \mathrm{R}$ bond and the other is to form the syn configurational complex by occupying the $\mathrm{Pd}$ and $\mathrm{W}$ atoms on the same side of the $\mathrm{P}-\mathrm{CS}_{2} \mathrm{R}$ bond.

In the reaction of $\mathbf{1}$ and $\mathbf{2}$, the complex trans-[W(CO) $\left.)_{4}\left(\mathrm{PPh}_{3}\right)_{2}\right]$ (5) is also isolated. Hieber ${ }^{33}$ and co-workers synthesized it 40 years ago. An improved preparation of tertiary phosphines and related substitution products of group VI metal carbonyls in high yields through sodium borohydride catalysis in boiling ethanol was developed by Chatt ${ }^{34}$ in 1971.

Disproportionation Reaction of Complex 3. At roomtemperature, complex $\mathbf{3}$ is unstable in $\mathrm{CHCl}_{3}$ and slowly forms the complex $\left[\mathrm{Pd}\left(\mathrm{PPh}_{3}\right)\left[\mathrm{PPh}_{2}\left(\mathrm{CS}_{2} \mathrm{Me}\right)\right]\right]_{2}(6)$ in $31 \%$ isolated yield and the complex $\left[\mathrm{W}(\mathrm{CO})_{5}\left(\mathrm{PPh}_{3}\right)\right](7)$ in $40 \%$ yield (Scheme 1). Compound $\mathbf{6}$ is an air-stable, yellow solid that is readily soluble in polar organic solvents such as dichloromethane, toluene, and acetonitrile but insoluble in saturated hydrocarbons.

The identification of 6 as $\left[\mathrm{Pd}\left(\mathrm{PPh}_{3}\right)\left[\mathrm{PPh}_{2}\left(\mathrm{CS}_{2} \mathrm{Me}\right)\right]\right]_{2}$ was based on the spectroscopic data. The FAB mass spectrum of 6 shows a peak at $m / z 1243$ which corresponds to a fragment formed by the cleavage of the SMe group from 6 . The ${ }^{1} \mathrm{H}$ NMR spectrum of $\mathbf{6}$ exhibits a singlet at $\delta 2.18$ assignable to the thiomethoxy protons, and the corresponding ${ }^{13} \mathrm{C}\left\{{ }^{1} \mathrm{H}\right\} \mathrm{NMR}$ signal is at $\delta$ 19.7. A downfield singlet at $\delta 53.7$ without a tungsten satellite in the ${ }^{31} \mathrm{P}\left\{{ }^{1} \mathrm{H}\right\}$ NMR spectrum is assigned to the $\mathrm{PPh}_{2}\left(\mathrm{CS}_{2} \mathrm{Me}\right)$ ligand whereas a signal at higher field $(\delta 22.2)$ is due to the $\mathrm{PPh}_{3}$ group on $\mathrm{Pd}$. The ${ }^{13} \mathrm{C}\left\{{ }^{1} \mathrm{H}\right\}$ NMR spectrum of 6 displays one set of resonances for the $\mathrm{PPh}_{2}\left(\mathrm{CS}_{2} \mathrm{Me}\right)$ ligand. In addition, no carbonyl absorption in the IR spectrum and tungsten isotope distribution in the mass spectrum have been observed. It can be summarized that the diphenyl(dithiomethoxycarbonyl)phosphine ligand is transferred from tungsten to palladium to form a dipalladium complex.

(33) Hieber, W.; Peterhans, J. Z. Naturforsch. 1959, 14B, 462

(34) Chatt, J.; Leigh, G. J.; Thankarajan, N. J. Organomet. Chem. 1971, 29,105 
Table 1. Crystal Data and Refinement Details for Complexes 3, 6, 9a, and $\mathbf{1 1 d} \cdot \mathrm{CHCl}_{3}$

\begin{tabular}{|c|c|c|c|c|}
\hline & 3 & 6 & $9 \mathrm{a}$ & $11 \mathrm{~d} \cdot \mathrm{CHCl}_{3}$ \\
\hline empirical formula & $\mathrm{C}_{55} \mathrm{H}_{43} \mathrm{O}_{5} \mathrm{P}_{3} \mathrm{~S}_{2} \mathrm{PdW}$ & $\mathrm{C}_{64} \mathrm{H}_{56} \mathrm{P}_{4} \mathrm{~S}_{4} \mathrm{Pd}_{2}$ & $\mathrm{C}_{56} \mathrm{H}_{42} \mathrm{NO}_{5} \mathrm{P}_{3} \mathrm{~S}_{2} \mathrm{PdW}$ & $\mathrm{C}_{59} \mathrm{H}_{47} \mathrm{Cl}_{3} \mathrm{NO}_{5} \mathrm{P}_{3} \mathrm{~S}_{2} \mathrm{PdW}$ \\
\hline fw & 1231.22 & 1290.07 & 1256.23 & 1403.66 \\
\hline space group & $P \overline{1}$ & $P 2 / c$ & $P \overline{1}$ & $P \overline{1}$ \\
\hline$a, \AA$ & $10.920(3)$ & $15.106(3)$ & $11.125(3)$ & $11.692(3)$ \\
\hline$b, \AA$ & $14.707(5)$ & $9.848(3)$ & $14.089(4)$ & 13.602(9) \\
\hline$c, \AA$ & $16.654(5)$ & $20.528(4)$ & $17.947(7)$ & $18.471(10)$ \\
\hline$\alpha, \operatorname{deg}$ & $99.98(3)$ & & $80.13(3)$ & $81.29(5)$ \\
\hline$\beta, \operatorname{deg}$ & $93.75(3)$ & $104.85(2)$ & $80.39(3)$ & $80.88(3)$ \\
\hline$\gamma, \mathrm{deg}$ & $99.44(3)$ & & $89.76(2)$ & $88.82(1)$ \\
\hline$V, \AA^{3}$ & $2586.3(14)$ & 2934.2(12) & $2731.7(15)$ & $2867(3)$ \\
\hline$Z$ & 2 & 2 & 2 & 2 \\
\hline$\rho_{\text {calcd }}, \mathrm{g} \mathrm{cm}^{-3}$ & 1.581 & 1.46 & 1.527 & 1.626 \\
\hline$\mu($ Mo K $\alpha), \mathrm{cm}^{-1}$ & 28.268 & 8.843 & 26.785 & 25.538 \\
\hline$\lambda, \AA$ & 0.70930 & 0.71073 & 0.71073 & 0.71073 \\
\hline$T,{ }^{\circ} \mathrm{C}$ & 25 & 25 & 25 & 25 \\
\hline$R^{a}$ & 0.040 & 0.034 & 0.047 & 0.038 \\
\hline$R_{\mathrm{w}}{ }^{b}$ & 0.042 & 0.037 & 0.044 & 0.041 \\
\hline
\end{tabular}

Table 2. Selected Interatomic Distances $(\AA)$ and Angles (deg) for 3, 6, 9a, and 11d

\begin{tabular}{|c|c|c|c|}
\hline \multicolumn{2}{|c|}{ bond lengths } & \multicolumn{2}{|c|}{ bond angles } \\
\hline \multicolumn{4}{|c|}{ Compound $\mathbf{3}$} \\
\hline $\mathrm{W}-\mathrm{P}(3)$ & $2.542(2)$ & $\mathrm{Pd}-\mathrm{S}(1)-\mathrm{C}(6)$ & $62.9(3)$ \\
\hline $\mathrm{Pd}-\mathrm{P}(1)$ & $2.317(2)$ & $\mathrm{Pd}-\mathrm{C}(6)-\mathrm{S}(1)$ & $71.0(3)$ \\
\hline $\mathrm{Pd}-\mathrm{P}(2)$ & $2.364(2)$ & $\mathrm{S}(1)-\mathrm{Pd}-\mathrm{C}(6)$ & $46.09(21)$ \\
\hline $\mathrm{Pd}-\mathrm{S}(1)$ & $2.278(2)$ & $S(2)-C(6)-P d$ & $117.6(4)$ \\
\hline $\mathrm{Pd}-\mathrm{C}(6)$ & $2.145(8)$ & $\mathrm{W}-\mathrm{P}(3)-\mathrm{C}(6)$ & $114.1(3)$ \\
\hline $\mathrm{C}(6)-\mathrm{S}(1)$ & $1.736(8)$ & $\mathrm{P}(1)-\mathrm{Pd}-\mathrm{P}(2)$ & $105.73(8)$ \\
\hline$C(6)-S(2)$ & $1.794(8)$ & $\mathrm{P}(3)-\mathrm{C}(6)-\mathrm{Pd}$ & 124.1(4) \\
\hline$C(6)-P(3)$ & $1.871(8)$ & $\mathrm{P}(3)-\mathrm{C}(6)-\mathrm{S}(2)$ & $110.4(4)$ \\
\hline \multicolumn{4}{|c|}{ Compound 6} \\
\hline $\mathrm{Pd}-\mathrm{P}(1)$ & $2.310(1)$ & $\mathrm{Pd}-\mathrm{S}(1)-\mathrm{C}(1)$ & $61.14(16)$ \\
\hline $\mathrm{Pd}-\mathrm{P}(2)$ & $2.340(2)$ & $\mathrm{Pd}-\mathrm{C}(1)-\mathrm{S}(1)$ & $72.73(18)$ \\
\hline $\mathrm{Pd}-\mathrm{S}(1)$ & $2.296(1)$ & $\mathrm{S}(1)-\mathrm{Pd}-\mathrm{C}(1)$ & $46.13(13)$ \\
\hline $\mathrm{Pd}-\mathrm{C}(1)$ & $2.106(5)$ & $S(2)-C(1)-P d$ & $118.50(25)$ \\
\hline$C(1)-S(1)$ & $1.734(5)$ & $C(1)-P(1)-P d$ & $116.81(16)$ \\
\hline$C(1)-S(2)$ & $1.793(5)$ & $\mathrm{P}(1)-\mathrm{Pd}-\mathrm{P}(2)$ & 108.02(5) \\
\hline $\mathrm{C}(1)-\mathrm{P}(1)$ & $1.836(5)$ & $\mathrm{P}(1)-\mathrm{C}(1)-\mathrm{Pd}$ & $112.97(23)$ \\
\hline \multicolumn{4}{|c|}{ Compound 9a } \\
\hline $\mathrm{W}-\mathrm{P}(1)$ & $2.565(3)$ & $\mathrm{Pd}-\mathrm{S}(1)-\mathrm{C}(1)$ & $66.2(3)$ \\
\hline $\mathrm{Pd}-\mathrm{P}(3)$ & $2.333(3)$ & $\mathrm{Pd}-\mathrm{C}(1)-\mathrm{S}(1)$ & $68.1(3)$ \\
\hline $\mathrm{Pd}-\mathrm{P}(2)$ & $2.323(3)$ & $\mathrm{S}(1)-\mathrm{Pd}-\mathrm{C}(1)$ & $45.7(3)$ \\
\hline $\mathrm{Pd}-\mathrm{S}(1)$ & $2.249(3)$ & $S(2)-C(1)-P d$ & $111.1(5)$ \\
\hline $\mathrm{Pd}-\mathrm{C}(1)$ & $2.217(10)$ & $\mathrm{W}-\mathrm{P}(1)-\mathrm{C}(1)$ & 119.6(3) \\
\hline$C(1)-S(1)$ & $1.734(10)$ & $\mathrm{P}(2)-\mathrm{Pd}-\mathrm{P}(3)$ & $103.68(11)$ \\
\hline$C(1)-S(2)$ & $1.836(10)$ & $\mathrm{P}(1)-\mathrm{C}(1)-\mathrm{Pd}$ & $127.7(5)$ \\
\hline $\mathrm{C}(1)-\mathrm{P}(1)$ & $1.811(11)$ & $\mathrm{P}(1)-\mathrm{C}(1)-\mathrm{S}(2)$ & $113.9(5)$ \\
\hline \multicolumn{4}{|c|}{ Compound 11d } \\
\hline $\mathrm{W}-\mathrm{P}(1)$ & $2.558(3)$ & $\mathrm{Pd}-\mathrm{S}(1)-\mathrm{C}(1)$ & $66.6(3)$ \\
\hline $\mathrm{Pd}-\mathrm{P}(3)$ & $2.341(2)$ & $\mathrm{Pd}-\mathrm{C}(1)-\mathrm{S}(1)$ & $68.2(3)$ \\
\hline $\mathrm{Pd}-\mathrm{P}(2)$ & $2.344(3)$ & $\mathrm{S}(1)-\mathrm{Pd}-\mathrm{C}(1)$ & $45.18(20)$ \\
\hline $\mathrm{Pd}-\mathrm{S}(1)$ & $2.261(2)$ & $\mathrm{S}(2)-\mathrm{C}(1)-\mathrm{Pd}$ & $114.6(4)$ \\
\hline $\mathrm{Pd}-\mathrm{C}(1)$ & $2.235(8)$ & $\mathrm{W}-\mathrm{P}(1)-\mathrm{C}(1)$ & $120.6(3)$ \\
\hline$C(1)-S(1)$ & $1.727(8)$ & $\mathrm{P}(2)-\mathrm{Pd}-\mathrm{P}(3)$ & 104.00(9) \\
\hline$C(1)-S(2)$ & $1.813(8)$ & $\mathrm{P}(1)-\mathrm{C}(1)-\mathrm{Pd}$ & 124.3(4) \\
\hline $\mathrm{C}(1)-\mathrm{P}(1)$ & $1.846(8)$ & $\mathrm{P}(1)-\mathrm{C}(1)-\mathrm{S}(2)$ & 111.3(4) \\
\hline
\end{tabular}

We also performed an X-ray diffraction study of 6 . It ORTEP drawing with atom labeling is shown in Figure 2. Table 2 contains selected bond distances and angles. The two $\mathrm{Pd}\left(\mathrm{PPh}_{3}\right)$ fragments, which are related by a crystallographic inversion center, are held together by two doubly bridging $\mathrm{PPh}_{2} \mathrm{CS}_{2} \mathrm{Me}$ moieties. Each $\mathrm{PPh}_{2}\left(\mathrm{CS}_{2} \mathrm{Me}\right)$ ligand is $\pi$-bonded to one $\mathrm{Pd}$ atom through the $\mathrm{C}=\mathrm{S}$ linkage and $\sigma$-bonded to the other Pd through the phosphorus atom, resulting in a six-membered ring. The coordination around each $\mathrm{Pd}$ atom is a distorted square plane, the distortion being mainly due to the short bite of the $\mathrm{C}=\mathrm{S}$ linkage $\left[\mathrm{C}-\mathrm{Pd}-\mathrm{S}=46.13(13)^{\circ}\right]$ and the requirements of the

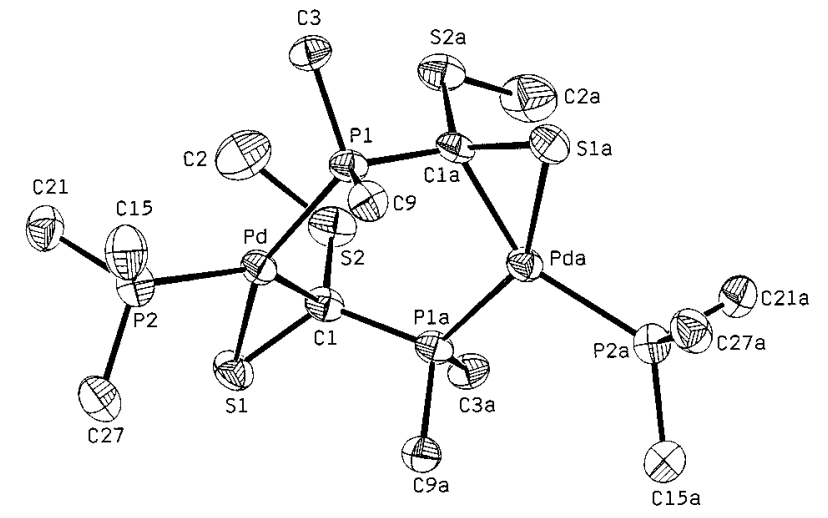

Figure 2. ORTEP plot of the molecular structure of compound $\mathbf{6}$. The phenyl groups are omitted for clarity.

six-membered ring. A least-squares plane calculation reveals the planarity of the $\mathrm{P}(2) \mathrm{P}(1) \mathrm{C}(1) \mathrm{S}(1)$ core (largest deviation $0.07(1) \AA$ ). The $\mathrm{Pd}-\mathrm{PPh}_{3}$ distance, $2.325(2) \AA$, is significantly longer than the corresponding value of 2.267(2) $\AA$ found in $\left[\mathrm{PdCl}\left(\mathrm{CH}_{2} \mathrm{SMe}\right)\left(\mathrm{PPh}_{3}\right)_{2}\right],{ }^{5}$ possibly because of the influence of the $\mathrm{C}=\mathrm{S}$ coordination.

In the literature, two six-membered-ring doubly $\mathrm{CS}_{2}$-bridged binuclear complexes, $\left[\left(\mathrm{PPh}_{3}\right) \mathrm{Ni}\left(\mu-\mathrm{CS}_{2}\right)_{2} \mathrm{Ni}\left(\mathrm{PPh}_{3}\right)\right]^{31}$ and $\left[\left(\mathrm{PPh}_{3}\right)\right.$ $\left.\mathrm{Pt}\left(\mu-\mathrm{CS}_{2}\right)_{2} \mathrm{Pt}\left(\mathrm{PPh}_{3}\right)\right],{ }^{32}$ were reported by Bianchini and Farrar. The differences between the doubly $\mathrm{CS}_{2}$-bridged and doubly $\mathrm{PPh}_{2}\left(\mathrm{CS}_{2} \mathrm{Me}\right)$-bridged complexes are due to the hybridization of the carbon atom of the $\mathrm{C}=\mathrm{S}$ moiety. Because of the $\mathrm{sp}^{3}$ hybridization of the $\mathrm{C}$ atom, the six-membered ring of complex 6 adopts a distorted chair conformation. However, $\mathrm{sp}^{2}$ hybridization of the $\mathrm{C}$ atom results in planarity of the $\mathrm{Ni}\left(\mu-\mathrm{CS}_{2}\right)_{2} \mathrm{Ni}$ entity (largest deviation from the mean plane $0.034 \AA$ ), creating the possibility of an overall electronic delocalization.

Thus, the (dithiomethoxycarbonyl)phosphine transfer reaction between $\left[\mathrm{Pd}\left(\mathrm{PPh}_{3}\right)_{4}\right]$ and $\left[\mathrm{W}(\mathrm{CO})_{5}\left[\mathrm{PPh}_{2}\left(\mathrm{CS}_{2} \mathrm{Me}\right)\right]\right]$ (2) forms $\left[\left[\left(\mathrm{Ph}_{3} \mathrm{P}\right) \mathrm{Pd}\left[\mu-\eta^{1}, \eta^{2}-\left(\mathrm{CS}_{2} \mathrm{Me}\right) \mathrm{PPh}_{2}\right]\right]_{2}\right](\mathbf{6})$ as the ultimate product. The reaction proceeds via an $\eta^{2}$-coordination of the $\mathrm{C}=\mathrm{S}$ fragment to $\mathrm{Pd}$, giving anti- $\left[\left(\mathrm{Ph}_{3} \mathrm{P}\right)_{2} \mathrm{Pd}\left[\mu-\eta^{1}, \eta^{2}-\left(\mathrm{CS}_{2} \mathrm{Me}\right) \mathrm{PPh}_{2}\right] \mathrm{W}-\right.$ $(\mathrm{CO})_{5}$ ] (3) as an intermediate. To the best of our knowledge, there is no previous report of diphenyl(dithiomethoxycarbonyl)phosphine acting as a doubly bridging ligand and of the phenomenon of a phosphine transfer reaction.

The $\mathrm{R}_{2} \mathrm{P}(\mathrm{S}) \mathrm{C}(\mathrm{S}) \mathrm{SR}$ ligand has successfully been used in reactions with $\left[\mathrm{Pt}\left(\mathrm{PPh}_{3}\right)_{2} \mathrm{C}_{2} \mathrm{H}_{4}\right]$ to form $\eta^{2}-\mathrm{CS}$ complexes. ${ }^{28}$ In an attempt to find another preparation method for complex $\mathbf{6}$, 


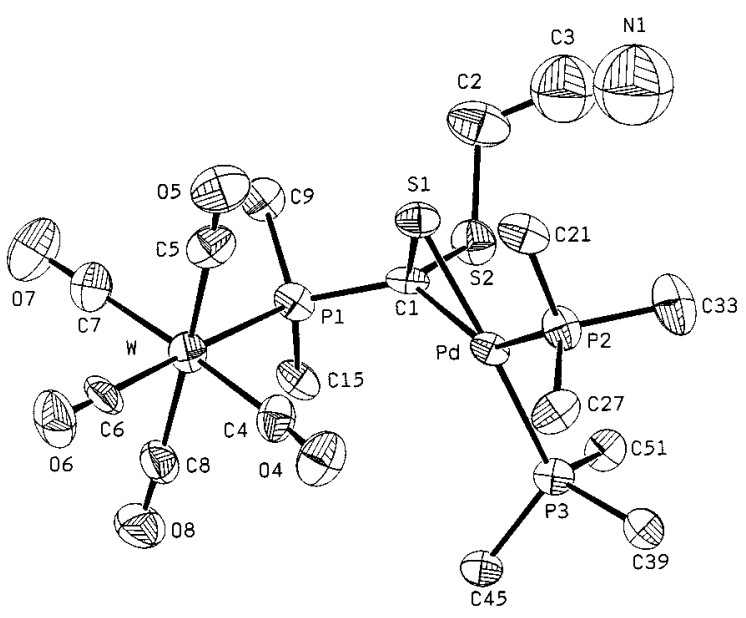

Figure 3. ORTEP plot of the molecular structure of compound 9a. The phenyl groups are omitted for clarity.

we treated $\mathrm{PPh}_{2}\left(\mathrm{CS}_{2} \mathrm{Me}\right)$ with $\mathrm{Pd}\left(\mathrm{PPh}_{3}\right)_{4}$ in $\mathrm{CH}_{2} \mathrm{Cl}_{2}$ at ambient temperature. Although the $\mathrm{C}=\mathrm{S} \pi$-coordination complex was observed, more than six other complexes were also found and the reaction was not pursued further. $\mathrm{Et}_{2} \mathrm{~N}\left(\mathrm{CS}_{2} \mathrm{Me}\right)$ and $\mathrm{Et}_{2} \mathrm{~N}$ $[\mathrm{C}(\mathrm{S}) \mathrm{NHPh}]$ were also treated with $\left[\mathrm{Pd}\left(\mathrm{PPh}_{3}\right)_{4}\right]$, but no reaction occurred even under extreme experimental conditions.

Synthesis of syn-[(Ph 3$)_{2} \mathbf{P d}\left[\mu-\eta^{1}, \eta^{2}-\left[\mathrm{CS}_{2}\left(\mathrm{CH}_{2}\right)_{n} \mathbf{C N}\right] \mathbf{P P h}_{2}\right] \mathrm{W}$ (CO) $)_{5}$ ( $\left.\boldsymbol{n}=\mathbf{1}, \mathbf{9 a} ; \boldsymbol{n}=\mathbf{2}, \mathbf{9 b}\right)$. The proposed differently configured complexes, $\mathbf{3}$ and $\mathbf{4}$, were identified only by their ${ }^{31} \mathrm{P}\left\{{ }^{1} \mathrm{H}\right\}$ NMR spectra. Unfortunately, we could not obtain a good-quality sample of the syn product $\mathbf{4}$ for X-ray diffraction analysis. Steric hindrance of the chemical reactions controls the reactive direction, which influences the stereoselectivity of the product. To explore the syn configurational complex, we carried out the reactions of the two hindered thionitrile complexes 8a,b with $\left[\mathrm{Pd}\left(\mathrm{PPh}_{3}\right)_{4}\right]($ Scheme 1).

The reactions of $\left[\mathrm{W}(\mathrm{CO})_{5}\left[\mathrm{PPh}_{2}\left[\mathrm{CS}_{2}\left(\mathrm{CH}_{2}\right)_{n} \mathrm{CN}\right]\right]\right](n=1, \mathbf{8 a}$; $n=2, \mathbf{8 b})$ with $\left[\mathrm{Pd}\left(\mathrm{PPh}_{3}\right)_{4}\right]$ in $\mathrm{CH}_{2} \mathrm{Cl}_{2}$ at room temperature were monitored by ${ }^{31} \mathrm{P}\left\{{ }^{1} \mathrm{H}\right\}$ NMR spectroscopy. Only one kind of product was detected which was identified as $s y n-\left[\left(\mathrm{Ph}_{3} \mathrm{P}\right)_{2^{-}}\right.$ $\left.\operatorname{Pd}\left[\mu-\eta^{1}, \eta^{2}-\mathrm{CS}_{2}\left(\mathrm{CH}_{2}\right)_{n} \mathrm{CNPPh}_{2}\right] \mathrm{W}(\mathrm{CO})_{5}\right](n=1, \mathbf{9 a} ; n=2, \mathbf{9 b})$ (Scheme 1). Complexes 9a and 9b were isolated in 85 and $90 \%$ yields, respectively. They are yellow, moderately air-stable, and readily soluble in chlorinated solvents but insoluble in nonpolar solvents. The FAB mass spectra show two base peaks at $\mathrm{m} / \mathrm{z}$ 1216 corresponding to $\left(\mathrm{Ph}_{3} \mathrm{P}\right)_{2} \mathrm{Pd}\left[\left(\mathrm{S}_{2} \mathrm{C}\right) \mathrm{PPh}_{2}\right] \mathrm{W}(\mathrm{CO})_{5}{ }^{+}$, formed by the loss of $\mathrm{CH}_{2} \mathrm{CN}$ and $\mathrm{C}_{2} \mathrm{H}_{4} \mathrm{CN}$ groups from $9 \mathbf{a}$ and $9 \mathbf{b}$, respectively. In the ${ }^{1} \mathrm{H} \mathrm{NMR}$ spectra of $\mathbf{9 a}$ and $\mathbf{9 b}, \mathrm{AB}$ resonances $(\delta 2.81,3.19)$ and two triplet resonances $(\delta 2.90$, 3.44) are respectively assignable to the thiomethylene and thioethylene protons. The corresponding ${ }^{13} \mathrm{C}\left\{{ }^{1} \mathrm{H}\right\}$ NMR signals appear at $\delta 20.1$ and at $\delta 15.2,21.7$, respectively. The ${ }^{31} \mathrm{P}\left\{{ }^{1} \mathrm{H}\right\}$ NMR spectrum of $9 \mathrm{a}$ exhibits a resonance at $\delta 54.2$ with a tungsten satellite $\left({ }^{1} J_{\mathrm{W}-\mathrm{P}}=255.0 \mathrm{~Hz},{ }^{3} J_{\mathrm{P}-\mathrm{P}}=10.0 \mathrm{~Hz}\right)$ and a small coupling with $\mathrm{PPh}_{3}$ on $\mathrm{Pd}$. Two other signals exhibit AB resonances at $\delta 22.5\left(\mathrm{dd},{ }^{2} J_{\mathrm{P}-\mathrm{P}}=37.1 \mathrm{~Hz},{ }^{3} J_{\mathrm{P}-\mathrm{P}}=10.0 \mathrm{~Hz}\right)$ and $\delta 24.7\left({ }^{2} J_{\mathrm{P}-\mathrm{P}}=37.1 \mathrm{~Hz}\right)$. The three ${ }^{31} \mathrm{P}\left\{{ }^{1} \mathrm{H}\right\}$ NMR resonances of 9b appear at $\delta 55.7\left({ }^{1} J_{\mathrm{W}-\mathrm{P}}=258.4 \mathrm{~Hz}\right), \delta 23.4$ $\left(\mathrm{dd},{ }^{2} J_{\mathrm{P}-\mathrm{P}}=33.5 \mathrm{~Hz},{ }^{3} J_{\mathrm{P}-\mathrm{P}}=7.9 \mathrm{~Hz}\right)$, and $\delta 24.2\left(\mathrm{~d},{ }^{2} J_{\mathrm{P}-\mathrm{P}}=\right.$ $33.5 \mathrm{~Hz}$ ), respectively. The most interesting point is that the ${ }^{31} \mathrm{P}\left\{{ }^{1} \mathrm{H}\right\}$ NMR patterns of $\mathbf{9 a}, \mathbf{b}$ are similar to that of $\mathbf{4}$. We thus believe that complexes $\mathbf{9 a}, \mathbf{b}$ and $\mathbf{4}$ have similar configurations.

To verify this hypothesis, the structure of complex 9a was determined identified by a single-crystal X-ray diffraction analysis. Figure 3 shows its ORTEP drawing with atom labeling of 9a. Selected bond distances and angles are listed in Table 2.

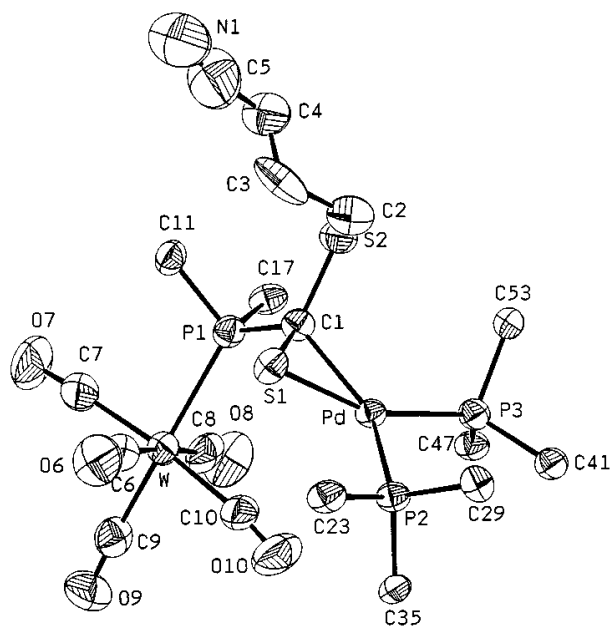

Figure 4. ORTEP plot of the molecular structure of compound 11d. The phenyl groups are omitted for clarity.

It is clear that the palladium and tungsten metal centers are in a syn configuration with respect to the $\mathrm{P}-\mathrm{CS}_{2}$ bond of the $\mathrm{PPh}_{2}\left(\mathrm{CS}_{2} \mathrm{CH}_{2} \mathrm{CN}\right)$ ligand. The $\mathrm{Pd}-\mathrm{S}(1)$ and $\mathrm{Pd}-\mathrm{C}(1)$ bond distances of 9a are 2.249(3) and 2.217(10) $\AA$, respectively, which are considered to be normal for $\mathrm{Pd}-\mathrm{S}$ bonds $(2.23-2.31$ $\AA$ ) and $\mathrm{Pd}-\mathrm{C}\left(\mathrm{sp}^{3}\right) \sigma$ bonds. ${ }^{5}$ The $\mathrm{C}(1)-\mathrm{Pd}, \mathrm{W}-\mathrm{P}(1)$, and $\mathrm{C}(1)-$ S(2)R bond distances of 2.217(10), 2.565(3), and 1.836(10) $\AA$ in 9a are longer than those of 2.145(8), 2.542(2), and 1.794(3) $\AA$, respectively, in 3 , but the $\mathrm{C}(1)-\mathrm{P}(1)(1.811(11) \AA)$ and $\mathrm{S}(1)-\mathrm{Pd}(2.249(3) \AA)$ bond distances in 9a are shorter than those in 3 [1.871(8) and 2.278(2) $\AA$, respectively]. This is due to the large steric hindrance of the syn configuration and can be confirmed by the W-Pd bond distances, 5.620(2) $\AA$ in 3 and 4.610(2) $\AA$ in 9a.

Reaction of $\left[\mathrm{W}(\mathrm{CO})_{5}\left[\mathrm{PPh}_{2}\left(\mathrm{CS}_{2} \mathrm{R}\right)\right]\right]\left(\mathrm{R}=\mathrm{C}_{2} \mathrm{H}_{5}, \mathrm{C}_{3} \mathrm{H}_{5}\right.$, $\left.\mathrm{C}_{2} \mathrm{H}_{4} \mathrm{OH}, \mathrm{C}_{3} \mathrm{H}_{6} \mathrm{CN}, 10 \mathrm{a}-\mathrm{d}\right)$ with $\left[\mathrm{Pd}\left(\mathrm{PPh}_{3}\right)_{4}\right]$. To investigate the factors that influence the stability of $\eta^{2}-\mathrm{CS}_{2}$ bonds to palladium and the configurations of the binuclear complexes, we extended the range of diphenyl(dithioalkoxycarbonyl)phosphine ligands in $\left[\mathrm{W}(\mathrm{CO})_{5}\left[\mathrm{PPh}_{2}\left(\mathrm{CS}_{2} \mathrm{R}\right)\right]\right]\left(\mathrm{R}=\mathrm{C}_{2} \mathrm{H}_{5}, \mathrm{C}_{3} \mathrm{H}_{5}\right.$, $\left.\mathrm{C}_{2} \mathrm{H}_{4} \mathrm{OH}, \mathrm{C}_{3} \mathrm{H}_{6} \mathrm{CN}, \mathbf{1 0 a}-\mathbf{d}\right)$. Complexes of the type syn$\left[\left[\left(\mathrm{Ph}_{3} \mathrm{P}\right)_{2} \mathrm{Pd}\left[\mu-\eta^{1}, \eta^{2}-\left(\mathrm{CS}_{2} \mathrm{R}\right) \mathrm{PPh}_{2}\right] \mathrm{W}(\mathrm{CO})_{5}\right]\right]\left(\mathrm{R}=\mathrm{C}_{2} \mathrm{H}_{5}, \mathrm{C}_{3} \mathrm{H}_{5}\right.$, $\left.\mathrm{C}_{2} \mathrm{H}_{4} \mathrm{OH}, \mathrm{C}_{3} \mathrm{H}_{6} \mathrm{CN}, \mathbf{1 1 a}-\mathbf{d}\right)$ were achieved by the reactions of $\left[\mathrm{W}(\mathrm{CO})_{5}\left[\mathrm{PPh}_{2}\left(\mathrm{CS}_{2} \mathrm{R}\right)\right]\right]\left(\mathrm{R}=\mathrm{C}_{2} \mathrm{H}_{5}, \mathrm{C}_{3} \mathrm{H}_{5}, \mathrm{C}_{2} \mathrm{H}_{4} \mathrm{OH}, \mathrm{C}_{3} \mathrm{H}_{6} \mathrm{CN}\right.$, 10a-d) with $\left[\mathrm{Pd}\left(\mathrm{PPh}_{3}\right)_{4}\right]$ in $\mathrm{CH}_{2} \mathrm{Cl}_{2}$. Compounds $\mathbf{1 1 a}-\mathbf{d}$ are air-stable, yellow solids and are readily soluble in polar organic solvents such as dichloromethane and acetonitrile, slightly soluble in tetrahydrofuran, and insoluble in saturated hydrocarbons. All of the spectroscopic and analytical data of $\mathbf{1 1 a}-\mathbf{d}$ are in agreement with their formulations. The most interesting observation is the ${ }^{31} \mathrm{P}\left\{{ }^{1} \mathrm{H}\right\}$ NMR pattern of these complexes. The ${ }^{31} \mathrm{P}\left\{{ }^{1} \mathrm{H}\right\}$ NMR spectrum of 11 a shows a resonance at $\delta$ 52.6 with a tungsten satellite $\left({ }^{1} J_{\mathrm{W}-\mathrm{P}}=249.0 \mathrm{~Hz}\right)$ and a singlet resonance at $\delta 22.7$ with a ratio of $1 / 2$, indicating that one $\mathrm{PPh}_{2^{-}}$ $\left(\mathrm{CS}_{2} \mathrm{C}_{2} \mathrm{H}_{5}\right)$ ligand is P-coordinated to $\mathrm{W}$ and two triphenylphosphines are coordinated to $\mathrm{Pd}$ in a cis geometry. Complex 11a is very stable in the solid state and does not decompose in air over a period of 1 week. The structures of $\mathbf{1 1 a}-\mathbf{d}$ were proposed to have syn configurations, which were proved by an X-ray structural analysis of 11d. Figure 4 shows its ORTEP diagram with atom labeling. Selected bond distances and angles are presented in Table 2. It is apparent that the palladium and tungsten metal centers are in a syn configuration with respect to the $\mathrm{P}-\mathrm{CS}_{2}$ bond of the $\mathrm{PPh}_{2}\left(\mathrm{CS}_{2} \mathrm{C}_{3} \mathrm{H}_{6} \mathrm{CN}\right)$ ligand and the thioalkoxy portion points away from the $\mathrm{Pd}$ metal. The $\mathrm{C}=\mathrm{S}$, 
$\mathrm{C}-\mathrm{Pd}, \mathrm{S}-\mathrm{Pd}, \mathrm{P}-\mathrm{CS}$, and $\mathrm{W}-\mathrm{P}$ bond distances of 11d are similar to those of compound $9 \mathbf{a}$ within experimental error. The $\mathrm{W}-\mathrm{Pd}$ bond distance in 11d, 4.575(3) $\AA$, is shorter than that $(5.620(2) \AA)$ in $\mathbf{3}$, indicating no bonding interaction between the two metal atoms. The conspicuously short $\mathrm{C}-\mathrm{SR}$ bond distance of 11d $(1.813(8) \AA)$ is attributed to the smaller hindrance between the $\mathrm{SC}_{3} \mathrm{H}_{6} \mathrm{CN}$ moiety and the $\mathrm{Pd}$ atom. To the best of our knowledge, the anti and syn dimetallic complexes $\mathbf{3}, \mathbf{9 a}, \mathbf{b}$, and $\mathbf{1 1 a}-\mathbf{d}$ are the first examples prepared with different $\mathrm{PPh}_{2}\left(\mathrm{CS}_{2} \mathrm{R}\right)$ ligands. Complexes $\mathbf{3}, \mathbf{9 a}, \mathbf{b}$, and $\mathbf{1 1 a}-\mathbf{d}$ show three kinds of ${ }^{31} \mathrm{P}\left\{{ }^{1} \mathrm{H}\right\}$ NMR patterns owing to the different thioalkoxy groups in $\left[\mathrm{W}(\mathrm{CO})_{5}\left[\mathrm{PPh}_{2}\left(\mathrm{CS}_{2} \mathrm{R}\right)\right]\right]$. The effects of the geometric positions of the two phosphorus atoms, the metal, and the remaining ligands and the types of substituents bound to phosphorus on the ${ }^{31} \mathrm{P}\left\{{ }^{1} \mathrm{H}\right\}$ NMR patterns and coupling constants of the $\left[\mathrm{Pd}(\mathrm{X})_{2}\left(\mathrm{PR}_{3}\right)_{2}\right]$ system have already been reported in the literature. ${ }^{35} \mathrm{We}$ attempted to produce dipalladium complexes like 6 from the disproportionation reactions of the two syn configurational complexes 9a and 11a, but neither reaction occurred nor was there any exchange of the syn and anti configurations, even by refluxing in $\mathrm{CHCl}_{3}$ for $1 \mathrm{~h}$.

\section{Conclusion}

We have compared the reactions of a range of diphenyl(dithioalkoxycarbonyl)phosphine complexes $\left[\mathrm{W}(\mathrm{CO})_{5}\left[\mathrm{PPh}_{2-}\right.\right.$ $\left.\left.\left(\mathrm{CS}_{2} \mathrm{R}\right)\right]\right]$ with $\left[\mathrm{Pd}\left(\mathrm{PPh}_{3}\right)_{4}\right] . \mathrm{PPh}_{2}\left(\mathrm{CS}_{2} \mathrm{R}\right)$, which acts as a bridging ligand through phosphorus $\sigma$-bonding and $\mathrm{C}=\mathrm{S} \pi$-bonding forms syn and anti configurational dimetallic complexes. The diphenyl(dithiomethoxycarbonyl)phosphine transfer reaction between $\left[\mathrm{Pd}\left(\mathrm{PPh}_{3}\right)_{4}\right]$ and $\left[\mathrm{W}(\mathrm{CO})_{5}\left[\mathrm{PPh}_{2}\left(\mathrm{CS}_{2} \mathrm{Me}\right)\right]\right]$ (2) forms $\left[\left[\left(\mathrm{Ph}_{3} \mathrm{P}\right) \mathrm{Pd}\left[\mu-\eta^{1}, \eta^{2}-\left(\mathrm{CS}_{2} \mathrm{Me}\right) \mathrm{PPh}_{2}\right]\right]_{2}\right]$ (6) as the ultimate product. The reaction proceeds via a $\eta^{2}$-coordination of the $\mathrm{C}=\mathrm{S}$ fragment to $\mathrm{Pd}$, giving anti- $\left[\left(\mathrm{Ph}_{3} \mathrm{P}\right)_{2} \mathrm{Pd}\left[\mu-\eta^{1}, \eta^{2}-\left(\mathrm{CS}_{2} \mathrm{Me}\right) \mathrm{PPh}_{2}\right] \mathrm{W}-\right.$ $(\mathrm{CO})_{5}$ ] (3) as an intermediate. Increased hindrance of the thioalkoxy groups exerts stereospecific control leading to the formation of syn configurational complexes. Useful ${ }^{31} \mathrm{P}\left\{{ }^{1} \mathrm{H}\right\}$ NMR patterns are able to differentiate configurational compounds. In the syn form, one of the triphenylphosphines couples with $\mathrm{PPh}_{2}\left(\mathrm{CS}_{2} \mathrm{R}\right)$ to give a doublet of doublet resonance or only one singlet resonance when the thioalkoxy group is oriented away from the Pd metal. In the anti form, the two singlet resonances of the triphenylphosphines on $\mathrm{Pd}$ do not couple with the response of the $\mathrm{PPh}_{2}\left(\mathrm{CS}_{2} \mathrm{R}\right)$ ligand on $\mathrm{W}$.

\section{Experimental Section}

All manipulations were performed under nitrogen using vacuumline, drybox, and standard Schlenk techniques. NMR spectra were recorded on a Bruker AM-200 or a Bruker AM-300 WB FT-NMR spectrometer and are reported in units of parts per million with residual protons in the solvent as an internal standard $\left(\mathrm{CDCl}_{3}, \delta 7.24 ; \mathrm{CD}_{3} \mathrm{CN}\right.$, $\left.\delta 1.93 ; \mathrm{C}_{6} \mathrm{D}_{6}, \delta 7.15 ; \mathrm{CD}_{3} \mathrm{COCD}_{3}, \delta 2.04\right)$. IR spectra were measured on a Perkin-Elmer 983 instrument and referenced to a polystyrene standard, using cells equipped with calcium fluoride windows. Mass spectra were recorded on a JEOL SX-102A spectrometer. Solvents were dried and deoxygenated by refluxing over the appropriate reagents before use. $n$-Hexane, diethyl ether, THF, and benzene were distilled from sodium-benzophenone. Acetonitrile and dichloromethane were distilled from calcium hydride, and methanol was distilled from magnesium. All other solvents and reagents were of reagent grade and were used as received. The compounds $\left[\mathrm{W}(\mathrm{CO})_{5}\left[\mathrm{PPh}_{2}\left(\mathrm{CS}_{2} \mathrm{R}\right)\right]\right]^{29}(\mathrm{R}$ $\left.=\mathrm{CH}_{3}, \mathrm{C}_{2} \mathrm{H}_{5}, \mathrm{C}_{3} \mathrm{H}_{5}, \mathrm{C}_{2} \mathrm{H}_{4} \mathrm{OH}, \mathrm{CH}_{2} \mathrm{CN}, \mathrm{CH}_{2} \mathrm{CH}_{2} \mathrm{CN}, \mathrm{CH}_{2} \mathrm{CH}_{2} \mathrm{CH}_{2} \mathrm{CN}\right)$ and $\left[\mathrm{Pd}\left(\mathrm{PPh}_{3}\right)_{4}\right]^{36}$ were prepared according to the literature methods.

(35) Diehl, P.; Fluck, E.; Kosfeld, R. ${ }^{31} P$ and ${ }^{13} C$ NMR of Transition Metal Phosphine Complexes; Springer-Verlag: Berlin, 1979.

(36) Malatesta, L.; Angeoletta, M. J. Chem. Soc. 1957, 1186.
Elemental analyses and X-ray diffraction studies were carried out at the Regional Center of Analytical Instrumentation located at the National Taiwan University.

anti-[( $\left.\left.\mathbf{P h}_{3} \mathbf{P}\right)_{2} \mathbf{P d}\left[\mu-\eta^{1}, \eta^{2}-\left(\mathrm{CS}_{2} \mathbf{M e}\right) \mathbf{P P h}_{2}\right] \mathrm{W}(\mathrm{CO})_{5}\right](3), \operatorname{syn}-\left[\left(\mathbf{P h}_{3} \mathbf{P}\right)_{2} \mathbf{P d}-\right.$ $\left.\left[\mu-\eta^{1}, \eta^{2}-\left(\mathbf{C S}_{2} \mathrm{Me}\right) \mathbf{P P h}_{2}\right] \mathrm{W}(\mathrm{CO})_{5}\right](4)$, and trans-[W(CO) $\left.)_{4}\left(\mathbf{P P h}_{3}\right)_{2}\right](5)$. Diethyl ether $(30 \mathrm{~mL})$ was added to a flask $(100 \mathrm{~mL})$ containing [Pd$\left.\left(\mathrm{PPh}_{3}\right)_{4}\right](\mathbf{1})(1.155 \mathrm{~g}, 1.0 \mathrm{mmol})$ and $\left[\mathrm{W}(\mathrm{CO})_{5}\left[\mathrm{PPh}_{2}\left(\mathrm{CS}_{2} \mathrm{Me}\right)\right]\right]$ (2) $(0.600 \mathrm{~g}, 1.0 \mathrm{mmol})$. The solution was refluxed for $3 \mathrm{~min}$, and the ${ }^{31} \mathrm{P}\left\{{ }^{1} \mathrm{H}\right\}$ NMR spectrum indicated that the reaction was complete. The solvent was removed under reduced pressure, and the residue was purified by chromatography on activated silica gel (length of column $20 \mathrm{~cm}) . \mathrm{PPh}_{3}$ was eluted with diethyl ether. Three fractions were separated with $1 / 5 \mathrm{CH}_{2} \mathrm{Cl}_{2}$ /diethyl ether. The yellow product from band 1 was concentrated and cooled to $-18{ }^{\circ} \mathrm{C}$ for $12 \mathrm{~h}$ to give a crystalline solid. This product was recrystallized from $2 / 1 n$-hexane/ $\mathrm{CH}_{2} \mathrm{Cl}_{2}$ to give the yellow complex anti-[( $\left.\left.\mathrm{Ph}_{3} \mathrm{P}\right)_{2} \mathrm{Pd}\left[\mu-\eta^{1}, \eta^{2}-\left(\mathrm{CS}_{2} \mathrm{Me}\right) \mathrm{PPh}_{2}\right] \mathrm{W}(\mathrm{CO})_{5}\right](3)$. Yield: $0.68 \mathrm{~g}, 55 \%$. IR (KBr, cm $\left.{ }^{-1}\right): v(\mathrm{CO}) 2060$ (m), 1914 (vs), 1887 (s). ${ }^{31} \mathrm{P}\left\{{ }^{1} \mathrm{H}\right\}$ NMR $\left(81 \mathrm{MHz}, \mathrm{CDCl}_{3}, 298 \mathrm{~K}\right): \delta 22.2,22.4\left(\mathrm{br}, \mathrm{PPh}_{3}\right)$, $51.6\left({ }^{1} J_{\mathrm{W}-\mathrm{P}}=257.6 \mathrm{~Hz}, \mathrm{PPh}_{2} \mathrm{CS}_{2} \mathrm{Me}\right) .{ }^{1} \mathrm{H} \mathrm{NMR}\left(200 \mathrm{MHz}, \mathrm{CDCl}_{3}\right.$, $298 \mathrm{~K}): \delta 2.09\left(\mathrm{~s}, 3 \mathrm{H}, \mathrm{SCH}_{3}\right), 7.0-7.4(\mathrm{~m}, 40 \mathrm{H}, \mathrm{Ph}) .{ }^{13} \mathrm{C}\left\{{ }^{1} \mathrm{H}\right\} \mathrm{NMR}$ $\left(50 \mathrm{MHz}, \mathrm{CDCl}_{3}, 298 \mathrm{~K}\right): \delta 18.7\left(\mathrm{~s}, \mathrm{SCH}_{3}\right), 127-134(\mathrm{~m}, \mathrm{C}$ of $\mathrm{Ph})$, $198.8\left(\mathrm{~d},{ }^{2} J_{\mathrm{P}-\mathrm{C}}=6.7 \mathrm{~Hz}\right.$, cis CO), $208.2\left(\mathrm{~s}, \mathrm{CS}_{2}\right), 214.9(\mathrm{~s}$, trans CO). MS (FAB, NBA, $m / z)$ : $1231\left[\mathrm{M}^{+}\right], 1216\left[\mathrm{M}^{+}-\mathrm{CH}_{3}\right]$. Anal. Calcd for $\mathrm{C}_{55} \mathrm{H}_{43} \mathrm{O}_{5} \mathrm{P}_{3} \mathrm{PdS}_{2} \mathrm{~W}$ : C, 53.65; H, 3.52. Found: C, 53.41; H, 3.65. The yellow-orange product from band 2 was recrystallized from $5 / 1$ $n$-hexane $/ \mathrm{CH}_{2} \mathrm{Cl}_{2}$ to give the complex syn- $\left[\left(\mathrm{Ph}_{3} \mathrm{P}\right)_{2} \mathrm{Pd}\left[\mu-\eta \eta^{1}, \eta^{2}-\left(\mathrm{CS}_{2} \mathrm{Me}\right)-\right.\right.$ $\mathrm{PPh}_{2}$ ]W(CO) $)_{5}$ (4). Yield: $0.12 \mathrm{~g}, 10 \%$. IR $\left(\mathrm{KBr}, \mathrm{cm}^{-1}\right): v(\mathrm{CO}) 2059$ (m), 1914 (sh), 1875 (s). ${ }^{31} \mathrm{P}\left\{{ }^{1} \mathrm{H}\right\}$ NMR (81 MHz, $\left.\mathrm{CDCl}_{3}, 298 \mathrm{~K}\right): \delta$ $21.7\left(\mathrm{~d},{ }^{2} J_{\mathrm{P}-\mathrm{P}}=39.1 \mathrm{~Hz}, \mathrm{PPh}_{3}\right), 25.2\left(\mathrm{dd},{ }^{3} J_{\mathrm{P}-\mathrm{P}}=7.0 \mathrm{~Hz},{ }^{2} J_{\mathrm{P}-\mathrm{P}}=\right.$ $\left.39.1 \mathrm{~Hz}, \mathrm{PPh}_{3}\right), 28.8\left(\mathrm{~d},{ }^{1} J_{\mathrm{W}-\mathrm{P}}=204.5 \mathrm{~Hz},{ }^{3} J_{\mathrm{P}-\mathrm{P}}=7.0 \mathrm{~Hz}, \mathrm{PPh}_{2} \mathrm{CS}_{2^{-}}\right.$ Me). ${ }^{1} \mathrm{H}$ NMR $\left(200 \mathrm{MHz}, \mathrm{CDCl}_{3}, 298 \mathrm{~K}\right): \delta 2.22$ (s, 3H, $\left.\mathrm{SCH}_{3}\right), 7.0-$ $7.4(\mathrm{~m}, 40 \mathrm{H}, \mathrm{Ph})$. MS (FAB, NBA, $m / z): 1231\left[\mathrm{M}^{+}\right]$. The orange-red complex from band 3 is trans-[W(CO) $\left.)_{4}\left(\mathrm{PPh}_{3}\right)_{2}\right](\mathbf{5})$. Yield: $0.16 \mathrm{~g}, 20 \%$. IR $\left(\mathrm{KBr}, \mathrm{cm}^{-1}\right): \quad v(\mathrm{CO}) 1873(\mathrm{~s}) .{ }^{31} \mathrm{P}\left\{{ }^{1} \mathrm{H}\right\} \mathrm{NMR}\left(81 \mathrm{MHz}, \mathrm{CDCl}_{3}\right.$, $298 \mathrm{~K}): \delta 27.7\left({ }^{1} J_{\mathrm{W}-\mathrm{P}}=281.3 \mathrm{~Hz}, \mathrm{PPh}_{3}\right) .{ }^{1} \mathrm{H}$ NMR $\left(200 \mathrm{MHz}, \mathrm{CDCl}_{3}\right.$, $298 \mathrm{~K}): \delta 7.4-7.6(\mathrm{~m}, 30 \mathrm{H}, \mathrm{Ph}) \cdot{ }^{13} \mathrm{C}\left\{{ }^{1} \mathrm{H}\right\} \mathrm{NMR}\left(50 \mathrm{MHz}, \mathrm{CDCl}_{3}\right.$, $298 \mathrm{~K}): \delta 127-134(\mathrm{~m}, \mathrm{C}$ of Ph). MS (FAB, NBA, $m / z): 819\left[\mathrm{M}^{+}\right]$. Anal. Calcd for $\mathrm{C}_{40} \mathrm{H}_{30} \mathrm{O}_{4} \mathrm{P}_{2} \mathrm{~W}$ : C, 58.55; H, 3.69. Found: C, 58.85; $\mathrm{H}, 3.53$.

$\left[\left[\left(\mathbf{P h}_{3} \mathbf{P}\right) \mathbf{P d}\left[\boldsymbol{\mu}-\boldsymbol{\eta}^{1}, \boldsymbol{\eta}^{2}-\left(\mathrm{CS}_{2} \mathrm{Me}\right) \mathbf{P P h}_{2}\right]\right]_{2}\right](6)$ and $\left[\mathrm{W}(\mathrm{CO})_{5}\left(\mathbf{P P h}_{3}\right)\right](7)$. $\mathrm{A} \mathrm{CHCl}_{3}(10 \mathrm{~mL})$ solution of $3(0.123 \mathrm{~g}, 0.1 \mathrm{mmol})$ was stirred at room temperature for $1 \mathrm{~h}$, and the ${ }^{31} \mathrm{P}\left\{{ }^{1} \mathrm{H}\right\}$ NMR spectrum indicated that the reaction was complete. The solvent was removed, and recrystallization from $2 / 1 n$-hexane/ $\mathrm{CH}_{2} \mathrm{Cl}_{2}$ gave the yellow crystalline product $\left[\left[\left(\mathrm{Ph}_{3} \mathrm{P}\right) \mathrm{Pd}\left[\mu-\eta^{1}, \eta^{2}-\left(\mathrm{CS}_{2} \mathrm{Me}\right) \mathrm{PPh}_{2}\right]\right]_{2}\right]$ (6). Yield: $0.04 \mathrm{~g}, 31 \%$. ${ }^{31} \mathrm{P}\left\{{ }^{1} \mathrm{H}\right\}$ NMR $\left(81 \mathrm{MHz}, \mathrm{CDCl}_{3}, 298 \mathrm{~K}\right): \delta 22.2\left(\mathrm{~s}, \mathrm{PPh}_{3}\right), 53.7(\mathrm{~s}$, $\mathrm{PPh}_{2} \mathrm{CS}_{2} \mathrm{Me}$ ). ${ }^{1} \mathrm{H}$ NMR $\left(200 \mathrm{MHz}, \mathrm{CDCl}_{3}, 298 \mathrm{~K}\right): \delta 2.18(\mathrm{~s}, 6 \mathrm{H}$, $\left.\mathrm{SCH}_{3}\right), 7.0-7.4(\mathrm{~m}, 50 \mathrm{H}, \mathrm{Ph}) .{ }^{13} \mathrm{C}\left\{{ }^{1} \mathrm{H}\right\}$ NMR $\left(50 \mathrm{MHz}, \mathrm{CDCl}_{3}, 298\right.$ $\mathrm{K}): \delta 19.7\left(\mathrm{~s}, \mathrm{SCH}_{3}\right), 127-134(\mathrm{~m}, \mathrm{C}$ of $\mathrm{Ph}), 198.1\left(\mathrm{~d},{ }^{1} J_{\mathrm{P}-\mathrm{C}}=26.5\right.$ $\left.\mathrm{Hz}, \mathrm{PCS}_{2}\right)$. MS (FAB, NBA, $\left.m / z\right): 1243\left[\mathrm{M}^{+}-\mathrm{SCH}_{3}\right], 981\left[\mathrm{M}^{+}-\right.$ $\mathrm{SCH}_{3}-\mathrm{PPh}_{3}$ ]. Anal. Calcd for $\mathrm{C}_{64} \mathrm{H}_{56} \mathrm{P}_{4} \mathrm{Pd}_{2} \mathrm{~S}_{4}:$ C, 59.58; H, 4.38. Found: C, 59.24; $\mathrm{H}, 4.60$. Another yellow complex, $\left[\mathrm{W}(\mathrm{CO})_{5}\left(\mathrm{PPh}_{3}\right)\right]$ (7), was isolated from the reaction in $40 \%$ yield. IR $\left(\mathrm{KBr}, \mathrm{cm}^{-1}\right): \nu$ (CO) 2060 (m), 1914 (vs), 1887 (s). ${ }^{31} \mathrm{P}\left\{{ }^{1} \mathrm{H}\right\}$ NMR (81 MHz, CDCl ${ }_{3}$, $298 \mathrm{~K}): \delta-10.2\left({ }^{1} J_{\mathrm{W}-\mathrm{P}}=257.2 \mathrm{~Hz}, \mathrm{PPh}_{3}\right) .{ }^{1} \mathrm{H}$ NMR $(200 \mathrm{MHz}$, $\left.\mathrm{CDCl}_{3}, 298 \mathrm{~K}\right): \delta 7.0-7.4(\mathrm{~m}, 15 \mathrm{H}, \mathrm{Ph}) .{ }^{13} \mathrm{C}\left\{{ }^{1} \mathrm{H}\right\}$ NMR $(50 \mathrm{MHz}$, $\left.\mathrm{CDCl}_{3}, 298 \mathrm{~K}\right): \delta$ 127-134 (m, C of Ph), 213.6, 214.9 (s, CO). MS $(\mathrm{FAB}, \mathrm{NBA}, \mathrm{m} / \mathrm{z}): 586\left[\mathrm{M}^{+}\right], 558\left[\mathrm{M}^{+}-\mathrm{CO}\right]$.

syn- $\left[\left(\mathbf{P h}_{3} \mathbf{P}\right)_{2} \mathbf{P d}\left[\boldsymbol{\mu}-\boldsymbol{\eta}^{1}, \boldsymbol{\eta}^{2}-\left(\mathrm{CS}_{2} \mathrm{CH}_{2} \mathbf{C N}\right) \mathbf{P P h}_{2}\right] \mathrm{W}(\mathrm{CO})_{5}\right](\mathbf{9 a}) . \mathrm{A} \mathrm{CH}_{2-}$ $\mathrm{Cl}_{2}(10 \mathrm{~mL})$ solution of $8 \mathbf{a}(0.313 \mathrm{~g}, 0.5 \mathrm{mmol})$ was added to a suspension of $\left[\mathrm{Pd}\left(\mathrm{PPh}_{3}\right)_{4}\right](0.576 \mathrm{~g}, 0.5 \mathrm{mmol})$ in $10 \mathrm{~mL}$ of $n$-hexane. After the mixture was stirred for $3 \mathrm{~min}$, the orange-yellow solution was evaporated to dryness. The residue was washed five times with $n$-hexane (each $10 \mathrm{~mL}$ ) to give a yellow precipitate, which was collected by filtration (G4) and dried in vacuo. Crystals of 9a were obtained from $\mathrm{CH}_{2} \mathrm{Cl}_{2} / n$-hexane by slow diffusion. The complex syn- $\left[\left(\mathrm{Ph}_{3} \mathrm{P}\right)_{2-}\right.$ $\left.\operatorname{Pd}\left[\mu-\eta \eta^{1}, \eta^{2}-\left(\mathrm{CS}_{2} \mathrm{CH}_{2} \mathrm{CN}\right) \mathrm{PPh}_{2}\right] \mathrm{W}(\mathrm{CO})_{5}\right](\mathbf{9 a})$ as a yellow microcrystalline solid was isolated in 85\% yield. IR $\left(\mathrm{KBr}, \mathrm{cm}^{-1}\right): v(\mathrm{CO}) 2064(\mathrm{~s})$, $1973(\mathrm{~m}), 1910$ (vs). ${ }^{31} \mathrm{P}\left\{{ }^{1} \mathrm{H}\right\}$ NMR $\left(81 \mathrm{MHz}, \mathrm{CDCl}_{3}, 298 \mathrm{~K}\right): \delta 22.5$ $\left(\mathrm{dd},{ }^{3} J_{\mathrm{P}-\mathrm{P}}=10.0 \mathrm{~Hz},{ }^{2} J_{\mathrm{P}-\mathrm{P}}=37.1 \mathrm{~Hz}, \mathrm{PPh}_{3}\right), 24.7\left(\mathrm{~d},{ }^{2} J_{\mathrm{P}-\mathrm{P}}=37.1\right.$ $\left.\mathrm{Hz}, \mathrm{PPh}_{3}\right), 54.2\left(\mathrm{~d},{ }^{1} J_{\mathrm{W}-\mathrm{P}}=255.0 \mathrm{~Hz},{ }^{3} J_{\mathrm{P}-\mathrm{P}}=10.0 \mathrm{~Hz}, \mathrm{PPh}_{2} \mathrm{CS}_{2}\right) .{ }^{1} \mathrm{H}$ 
NMR $\left(200 \mathrm{MHz}, \mathrm{CDCl}_{3}, 298 \mathrm{~K}\right): \delta 2.81\left(\mathrm{~d},{ }^{2} J_{\mathrm{H}-\mathrm{H}}=16.4 \mathrm{~Hz}, 1 \mathrm{H}\right.$, $\left.\mathrm{SCH}_{2}\right), 3.19\left(\mathrm{~d},{ }^{2} J_{\mathrm{H}-\mathrm{H}}=16.4 \mathrm{~Hz}, 1 \mathrm{H}, \mathrm{SCH}_{2}\right), 7.0-7.4(\mathrm{~m}, 40 \mathrm{H}, \mathrm{Ph})$. ${ }^{13} \mathrm{C}\left\{{ }^{1} \mathrm{H}\right\}$ NMR $\left(50 \mathrm{MHz}, \mathrm{CDCl}_{3}, 298 \mathrm{~K}\right): \delta 20.1\left(\mathrm{~s}, \mathrm{SCH}_{2}\right), 117.7(\mathrm{~s}$, $\mathrm{CN}), 127-137$ (m, C of Ph), $198.6\left(\mathrm{~d},{ }^{2} J_{\mathrm{P}-\mathrm{C}}=6.7 \mathrm{~Hz}\right.$, cis-CO), 200.6 $\left(\mathrm{s}, \mathrm{CS}_{2}\right)$. MS (FAB, NBA, m/z): $1216\left[\mathrm{M}^{+}-\mathrm{CH}_{2} \mathrm{CN}\right], 1160\left[\mathrm{M}^{+}-\right.$ $\left.\mathrm{CH}_{2} \mathrm{CN}-2 \mathrm{CO}\right], 1076\left[\mathrm{M}^{+}-\mathrm{CH}_{2} \mathrm{CN}-5 \mathrm{CO}\right], 630\left[\mathrm{M}^{+}-\mathrm{CH}_{2} \mathrm{CN}\right.$ $-5 \mathrm{CO}-\mathrm{WPPh}_{2} \mathrm{CS}_{2}$ ]. Anal. Calcd for $\mathrm{C}_{56} \mathrm{H}_{42} \mathrm{NO}_{5} \mathrm{P}_{3} \mathrm{PdS}_{2} \mathrm{~W}: \mathrm{C}, 53.54$; $\mathrm{H}, 3.37$; N, 1.12. Found: C, 53.32; H, 3.62; N, 1.54.

syn- $\left[\left(\mathbf{P h}_{3} \mathbf{P}\right)_{2} \mathbf{P d}\left[\mu-\eta^{1}, \eta^{2}-\left(\mathrm{CS}_{2} \mathrm{CH}_{2} \mathrm{CH}_{2} \mathrm{CN}\right) \mathbf{P P h}_{2}\right] \mathbf{W}(\mathrm{CO})_{5}\right](\mathbf{9 b})$. The procedures for synthesis and workup were similar to those for $9 \mathbf{a}$. The yellow, microcrystalline complex syn- $\left[\left(\mathrm{Ph}_{3} \mathrm{P}\right)_{2} \mathrm{Pd}\left[\mu-\eta^{1}, \eta^{2}-\left(\mathrm{CS}_{2} \mathrm{CH}_{2} \mathrm{CH}_{2-}\right.\right.\right.$ $\left.\mathrm{CN}) \mathrm{PPh}_{2}\right] \mathrm{W}(\mathrm{CO})_{5}$ ] (9b) was isolated in $90 \%$ yield. IR (THF, $\mathrm{cm}^{-1}$ ): $v(\mathrm{CO}) 2072(\mathrm{~m}), 1972$ (vs). ${ }^{31} \mathrm{P}\left\{{ }^{1} \mathrm{H}\right\}$ NMR (81 MHz, $\left.\mathrm{CDCl}_{3}, 298 \mathrm{~K}\right):$ $\delta 23.4\left(\mathrm{dd},{ }^{3} J_{\mathrm{P}-\mathrm{P}}=7.9 \mathrm{~Hz},{ }^{2} J_{\mathrm{P}-\mathrm{P}}=33.5 \mathrm{~Hz}, \mathrm{PPh}_{3}\right), 24.2\left(\mathrm{~d},{ }^{2} J_{\mathrm{P}-\mathrm{P}}=\right.$ $\left.33.5 \mathrm{~Hz}, \mathrm{PPh}_{3}\right), 55.7\left(\mathrm{br},{ }^{1} J_{\mathrm{W}-\mathrm{P}}=258.4 \mathrm{~Hz}, \mathrm{PPh}_{2} \mathrm{CS}_{2}\right) .{ }^{1} \mathrm{H}$ NMR $(200$ $\left.\mathrm{MHz}, \mathrm{CDCl}_{3}, 298 \mathrm{~K}\right): \delta 2.90\left(\mathrm{t}, J_{\mathrm{H}-\mathrm{H}}=6.7 \mathrm{~Hz}, 2 \mathrm{H}, \mathrm{SCH}_{2}\right), 3.44(\mathrm{t}$, $\left.J_{\mathrm{H}-\mathrm{H}}=6.7 \mathrm{~Hz}, 2 \mathrm{H}, \mathrm{CH}_{2} \mathrm{CN}\right), 7.0-7.4(\mathrm{~m}, 40 \mathrm{H}, \mathrm{Ph}) .{ }^{13} \mathrm{C}\left\{{ }^{1} \mathrm{H}\right\} \mathrm{NMR}$ $\left(50 \mathrm{MHz}, \mathrm{CDCl}_{3}, 298 \mathrm{~K}\right): \delta 15.2\left(\mathrm{~s}, \mathrm{SCH}_{2}\right), 21.7\left(\mathrm{~s}, \mathrm{CH}_{2} \mathrm{CN}\right), 117.1$ (s, $\left.\mathrm{CH}_{2} \mathrm{CN}\right), 127-137(\mathrm{~m}, \mathrm{C}$ of $\mathrm{Ph}), 198.6\left(\mathrm{~d},{ }^{2} J_{\mathrm{P}-\mathrm{C}}=6.9 \mathrm{~Hz}\right.$, cis $\mathrm{CO}$ ), $200.6\left(\mathrm{~s}, \mathrm{CS}_{2}\right.$ ), 210.2 (s, trans CO). MS (FAB, NBA, $\left.m / z\right): 1216$ $\left[\mathrm{M}^{+}-\mathrm{C}_{2} \mathrm{H}_{4} \mathrm{CN}\right], 1076\left[\mathrm{M}^{+}-\mathrm{C}_{2} \mathrm{H}_{4} \mathrm{CN}-5 \mathrm{CO}\right], 630\left[\mathrm{M}^{+}-\mathrm{C}_{2} \mathrm{H}_{4} \mathrm{CN}\right.$ $-5 \mathrm{CO}-\mathrm{WPPh}_{2} \mathrm{CS}_{2}$ ]. Anal. Calcd for $\mathrm{C}_{57} \mathrm{H}_{44} \mathrm{NO}_{5} \mathrm{P}_{3} \mathrm{PdS}_{2} \mathrm{~W}$ : C, 53.89; $\mathrm{H}, 3.49$; N, 1.10. Found: C, 53.95; H, 3.60; N, 1.01.

syn $-\left[\left(\mathbf{P h}_{3} \mathbf{P}\right)_{2} \mathbf{P d}\left[\boldsymbol{\mu}-\eta^{1}, \eta^{2}-\left(\mathrm{CS}_{2} \mathrm{C}_{2} \mathrm{H}_{5}\right) \mathbf{P P h}_{2}\right] \mathbf{W}(\mathbf{C O})_{5}\right]$ (11a). $\mathrm{CH}_{2} \mathrm{Cl}_{2}$ $(10 \mathrm{~mL})$ was added to a flask $(50 \mathrm{~mL})$ containing $10 \mathrm{a}(0.307 \mathrm{~g}, 0.5$ $\mathrm{mmol})$ and $\left[\mathrm{Pd}\left(\mathrm{PPh}_{3}\right)_{4}\right](0.577 \mathrm{~g}, 0.5 \mathrm{mmol})$. The color of the solution turned from red to yellow in $3 \mathrm{~min}$. The solution was then evaporated to dryness. The yellow residue was stirred with $30 \mathrm{~mL}$ of $n$-hexane/ diethyl ether (2/1) to yield a yellow precipitate, which was crystallized from $\mathrm{CH}_{2} \mathrm{Cl}_{2} / n$-hexane by slow diffusion. The yellow crystals were collected and dried in vacuo to give the complex syn- $\left[\left(\mathrm{Ph}_{3} \mathrm{P}\right)_{2} \mathrm{Pd}[\mu-\right.$ $\left.\left.\eta^{1}, \eta^{2}-\left(\mathrm{CS}_{2} \mathrm{C}_{2} \mathrm{H}_{5}\right) \mathrm{PPh}_{2}\right] \mathrm{W}(\mathrm{CO})_{5}\right]$ (11a) in $82 \%$ yield. IR (THF, $\mathrm{cm}^{-1}$ ): $v(\mathrm{CO}) 2072(\mathrm{~m}), 1933$ (vs). ${ }^{31} \mathrm{P}\left\{{ }^{1} \mathrm{H}\right\}$ NMR (81 MHz, $\left.\mathrm{CDCl}_{3}, 298 \mathrm{~K}\right)$ : $\delta 22.7\left(\mathrm{~s}, \mathrm{PPh}_{3}\right), 52.6\left({ }^{1} J_{\mathrm{W}-\mathrm{P}}=249.0 \mathrm{~Hz}, \mathrm{PPh}_{2} \mathrm{CS}_{2}\right) .{ }^{1} \mathrm{H}$ NMR $(200$ $\left.\mathrm{MHz}, \mathrm{CDCl}_{3}, 298 \mathrm{~K}\right): \delta 1.29\left(\mathrm{t}, J_{\mathrm{H}-\mathrm{H}}=7.4 \mathrm{~Hz}, 3 \mathrm{H}, \mathrm{CH}_{3}\right), 3.30(\mathrm{q}$, $\left.J_{\mathrm{H}-\mathrm{H}}=7.4 \mathrm{~Hz}, 2 \mathrm{H}, \mathrm{SCH}_{2}\right), 7.0-7.4(\mathrm{~m}, 40 \mathrm{H}, \mathrm{Ph}) .{ }^{13} \mathrm{C}\left\{{ }^{1} \mathrm{H}\right\} \mathrm{NMR}(50$ $\left.\mathrm{MHz}, \mathrm{CDCl}_{3}, 298 \mathrm{~K}\right): \delta 12.7\left(\mathrm{~s}, \mathrm{CH}_{3}\right), 30.6\left(\mathrm{~s}, \mathrm{SCH}_{2}\right), 127-137(\mathrm{~m}$, $\mathrm{C}$ of $\mathrm{Ph}), 197.0\left(\mathrm{~d},{ }^{2} J_{\mathrm{P}-\mathrm{C}}=8.3 \mathrm{~Hz}\right.$, cis CO). MS (FAB, NBA, $\left.\mathrm{m} / \mathrm{z}\right)$ : $1245\left[\mathrm{M}^{+}\right], 1217\left[\mathrm{M}^{+}-\mathrm{CO}\right], 630\left[\mathrm{M}^{+}-\mathrm{W}(\mathrm{CO})_{5} \mathrm{PPh}_{2} \mathrm{CS}_{2} \mathrm{C}_{2} \mathrm{H}_{5}\right]$. Anal. Calcd for $\mathrm{C}_{56} \mathrm{H}_{45} \mathrm{O}_{5} \mathrm{P}_{3} \mathrm{PdS}_{2} \mathrm{~W}$ : C, 54.01; H, 3.64. Found: C, 54.31; H, 3.80 .

syn $-\left[\left(\mathbf{P h}_{3} \mathbf{P}\right)_{2} \mathbf{P d}\left[\mu-\eta^{1}, \eta^{2}-\left(\mathrm{CS}_{2} \mathrm{C}_{3} \mathrm{H}_{5}\right) \mathbf{P P h}_{2}\right] \mathbf{W}(\mathrm{CO})_{5}\right](\mathbf{1 1 b})$. The procedures for synthesis and workup were similar to those for complex 11a. The yellow, microcrystalline complex syn- $\left[\left(\mathrm{Ph}_{3} \mathrm{P}\right)_{2} \mathrm{Pd}\left[\mu-\eta^{1}, \eta^{2}-\right.\right.$ $\left.\left(\mathrm{CS}_{2} \mathrm{C}_{3} \mathrm{H}_{5}\right) \mathrm{PPh}_{2}\right] \mathrm{W}(\mathrm{CO})_{5}$ ] (11b) was isolated in $88 \%$ yield. IR (THF, $\left.\mathrm{cm}^{-1}\right): v(\mathrm{CO}) 2068(\mathrm{~m}), 1928(\mathrm{vs}) .{ }^{31} \mathrm{P}\left\{{ }^{1} \mathrm{H}\right\} \mathrm{NMR}\left(81 \mathrm{MHz}, \mathrm{CDCl}_{3}\right.$, $298 \mathrm{~K}): \delta 22.7\left(\mathrm{~s}, \mathrm{PPh}_{3}\right), 53.1\left({ }^{1} J_{\mathrm{W}-\mathrm{P}}=252.6 \mathrm{~Hz}, \mathrm{PPh}_{2} \mathrm{CS}_{2}\right) .{ }^{1} \mathrm{H} \mathrm{NMR}$ $\left(200 \mathrm{MHz}, \mathrm{CDCl}_{3}, 298 \mathrm{~K}\right): \delta 3.42\left(\mathrm{~d},{ }^{3} J_{\mathrm{H}-\mathrm{H}}=6.6 \mathrm{~Hz}, 2 \mathrm{H}, \mathrm{SCH}_{2}\right)$, $4.93\left(\mathrm{~m}, 2 \mathrm{H}, \mathrm{CHCH}_{2}\right), 5.66\left(\mathrm{~m}, 1 \mathrm{H}, \mathrm{CHCH}_{2}\right), 7.0-7.4(\mathrm{~m}, 40 \mathrm{H}, \mathrm{Ph})$. ${ }^{13} \mathrm{C}\left\{{ }^{1} \mathrm{H}\right\}$ NMR $\left(50 \mathrm{MHz}, \mathrm{CDCl}_{3}, 298 \mathrm{~K}\right): \delta 40.1\left(\mathrm{~s}, \mathrm{SCH}_{2}\right), 117.1(\mathrm{~s}$, $\mathrm{HC}=), 117.6\left(\mathrm{~s},=\mathrm{CH}_{2}\right), 127-137(\mathrm{~m}, \mathrm{C}$ of $\mathrm{Ph}), 198.8\left(\mathrm{~d},{ }^{2} J_{\mathrm{P}-\mathrm{C}}=6.9\right.$ $\mathrm{Hz}$, cis CO). MS (FAB, NBA, $m / z): 1257\left[\mathrm{M}^{+}\right], 1216\left[\mathrm{M}^{+}-\mathrm{C}_{3} \mathrm{H}_{5}\right]$, $630\left[\mathrm{M}^{+}-\mathrm{C}_{3} \mathrm{H}_{5}-\mathrm{W}(\mathrm{CO})_{5} \mathrm{PPh}_{2} \mathrm{CS}_{2}\right]$. Anal. Calcd for $\mathrm{C}_{57} \mathrm{H}_{45} \mathrm{O}_{5} \mathrm{P}_{3^{-}}$ $\mathrm{PdS}_{2} \mathrm{~W}$ : C, 54.45; H, 3.61. Found: C, 54.60; H, 3.82.

syn- $\left[\left(\mathbf{P h}_{3} \mathbf{P}\right)_{2} \mathbf{P d}\left[\mu-\eta^{1}, \eta^{2}-\left(\mathrm{CS}_{2} \mathrm{C}_{2} \mathrm{H}_{4} \mathrm{OH}\right) \mathbf{P P h}_{2}\right] \mathbf{W}(\mathrm{CO})_{5}\right]$ (11c). The procedures for synthesis and workup were similar to those for complex 11a. The yellow, microcrystalline complex syn- $\left[\left(\mathrm{Ph}_{3} \mathrm{P}\right)_{2} \mathrm{Pd}\left[\mu-\eta^{1}, \eta^{2}-\right.\right.$ $\left.\left(\mathrm{CS}_{2} \mathrm{C}_{2} \mathrm{H}_{4} \mathrm{OH}\right) \mathrm{PPh}_{2}\right] \mathrm{W}(\mathrm{CO})_{5}$ ] (11c) was isolated in $80 \%$ yield. IR (THF, $\left.\mathrm{cm}^{-1}\right): v(\mathrm{CO}) 2071(\mathrm{~m}), 1932$ (vs). ${ }^{31} \mathrm{P}\left\{{ }^{1} \mathrm{H}\right\}$ NMR (81 MHz, $\mathrm{CDCl}_{3}$, $298 \mathrm{~K}): \delta 23.6\left(\mathrm{~s}, \mathrm{PPh}_{3}\right), 55.3\left({ }^{1} J_{\mathrm{W}-\mathrm{P}}=255.8 \mathrm{~Hz}, \mathrm{PPh}_{2} \mathrm{CS}_{2}\right) .{ }^{1} \mathrm{H} \mathrm{NMR}$ $\left(200 \mathrm{MHz}, \mathrm{CDCl}_{3}, 298 \mathrm{~K}\right): \delta 3.52\left(\mathrm{~m}, 2 \mathrm{H}, \mathrm{SCH}_{2}\right), 3.78\left(\mathrm{~m}, 2 \mathrm{H}, \mathrm{CH}_{2} \mathrm{O}\right)$, 7.0-7.4 (m, 40H, Ph). ${ }^{13} \mathrm{C}\left\{{ }^{1} \mathrm{H}\right\}$ NMR $\left(50 \mathrm{MHz}, \mathrm{CDCl}_{3}, 298 \mathrm{~K}\right): \delta$ $39.4\left(\mathrm{~s}, \mathrm{SCH}_{2}\right), 60.8\left(\mathrm{~s}, \mathrm{CH}_{2} \mathrm{OH}\right), 127-137(\mathrm{~m}, \mathrm{C}$ of $\mathrm{Ph}), 197.1$ (d, ${ }^{2} J_{\mathrm{P}-\mathrm{C}}=8.3 \mathrm{~Hz}$, cis CO). MS (FAB, NBA, $\left.m / z\right): 1261\left[\mathrm{M}^{+}\right], 1216$ $\left[\mathrm{M}^{+}-\mathrm{CH}_{2} \mathrm{CH}_{2} \mathrm{OH}\right], 630\left[\mathrm{M}^{+}-\mathrm{C}_{2} \mathrm{H}_{5} \mathrm{OH}-\mathrm{W}(\mathrm{CO})_{5} \mathrm{PPh}_{2} \mathrm{CS}_{2}\right]$. Anal. Calcd for $\mathrm{C}_{56} \mathrm{H}_{45} \mathrm{O}_{6} \mathrm{P}_{3} \mathrm{PdS}_{2} \mathrm{~W}$ : C, 53.32; H, 3.60. Found: C, 53.75; H, 3.87.

syn- $\left[\left(\mathbf{P h}_{3} \mathbf{P}\right)_{2} \mathbf{P d}\left[\mu-\eta^{1}, \eta^{2}-\left(\mathrm{CS}_{2} \mathrm{C}_{3} \mathrm{H}_{6} \mathrm{CN}\right) \mathrm{PPh}_{2}\right] \mathrm{W}(\mathrm{CO})_{5}\right]$ (11d). The procedures for synthesis and workup were similar to those for complex 11a. The yellow, microcrystalline complex $s y n-\left[\left(\mathrm{Ph}_{3} \mathrm{P}\right)_{2} \mathrm{Pd}\left[\mu-\eta^{1}, \eta^{2}-\left(\mathrm{CS}_{2-}\right.\right.\right.$
$\left.\mathrm{CH}_{2} \mathrm{CH}_{2} \mathrm{CH}_{2} \mathrm{CN}\right) \mathrm{PPh}_{2}$ ]W(CO) $)_{5}$ ] (11d) was isolated in $92 \%$ yield. IR (THF, $\left.\mathrm{cm}^{-1}\right): \quad v(\mathrm{CO}) 2065$ (m), 1926 (vs). ${ }^{31} \mathrm{P}\left\{{ }^{1} \mathrm{H}\right\}$ NMR $(81 \mathrm{MHz}$, $\left.\mathrm{CDCl}_{3}, 298 \mathrm{~K}\right): \delta 23.3\left(\mathrm{~s}, \mathrm{PPh}_{3}\right), 54.5\left(\mathrm{br},{ }^{1} J_{\mathrm{W}-\mathrm{P}}=252.9 \mathrm{~Hz}, \mathrm{PPh}_{2-}\right.$ $\left.\mathrm{CS}_{2}\right) .{ }^{1} \mathrm{H}$ NMR $\left(200 \mathrm{MHz}, \mathrm{CDCl}_{3}, 298 \mathrm{~K}\right): \delta 1.80\left(\mathrm{~m}, 2 \mathrm{H}, \mathrm{CH}_{2} \mathrm{CH}_{2-}\right.$ $\mathrm{CN}), 2.16\left(\mathrm{t},{ }^{3} J_{\mathrm{H}-\mathrm{H}}=8.1 \mathrm{~Hz}, 2 \mathrm{H}, \mathrm{CH}_{2} \mathrm{CN}\right), 2.83\left(\mathrm{t},{ }^{3} J_{\mathrm{H}-\mathrm{H}}=8.1 \mathrm{~Hz}\right.$, $\left.2 \mathrm{H}, \mathrm{SCH}_{2}\right), 7.0-7.4(\mathrm{~m}, 40 \mathrm{H}, \mathrm{Ph}) .{ }^{13} \mathrm{C}\left\{{ }^{1} \mathrm{H}\right\}$ NMR $\left(50 \mathrm{MHz}, \mathrm{CDCl}_{3}\right.$, $298 \mathrm{~K}$ ): $\delta 16.0\left(\mathrm{~s}, \mathrm{CH}_{2} \mathrm{CH}_{2} \mathrm{CN}\right), 24.7\left(\mathrm{~s}, \mathrm{CH}_{2} \mathrm{CN}\right), 34.7\left(\mathrm{~s}, \mathrm{SCH}_{2}\right)$, $119.3(\mathrm{~s}, \mathrm{CN}), 127-137(\mathrm{~m}, \mathrm{C}$ of $\mathrm{Ph}), 198.6\left(\mathrm{~d},{ }^{2} J_{\mathrm{P}-\mathrm{C}}=6.9 \mathrm{~Hz}\right.$, cis $\mathrm{CO}), 212.5$ (s, $\mathrm{CS}_{2}$ ), 220.4 (s, trans CO). MS (FAB, NBA, $\left.m / z\right): 1284$ $\left[\mathrm{M}^{+}\right], 1216\left[\mathrm{M}^{+}-\mathrm{CH}_{2} \mathrm{CN}-\mathrm{CO}\right], 630\left[\mathrm{M}^{+}-\mathrm{CH}_{2} \mathrm{CN}-\mathrm{W}(\mathrm{CO})_{5} \mathrm{PPh}_{2}-\right.$ $\mathrm{CS}_{2} \mathrm{CH}_{2} \mathrm{CH}_{2}$ ]. Anal. Calcd for $\mathrm{C}_{58} \mathrm{H}_{46} \mathrm{NO}_{5} \mathrm{P}_{3} \mathrm{PdS}_{2} \mathrm{~W}$ : C, 54.24; H, 3.61; N, 1.09. Found: C, 54.62; H, 3.20; N, 0.98 .

Single-Crystal X-ray Diffraction Analyses of 3, 6, 9a, and 11d. Single crystals of $\mathbf{3}, \mathbf{6}, \mathbf{9 a}$, and 11d suitable for $\mathrm{X}$-ray diffraction analyses were grown by recrystallization from $20 / 1 n$-hexane $/ \mathrm{CH}_{2} \mathrm{Cl}_{2}$. The diffraction data were collected at room temperature on an EnrafNonius CAD4 diffractometer equipped with graphite-monochromated Mo $\mathrm{K} \alpha(\lambda=0.71073 \AA)$ radiation. The raw intensity data were converted to structure factor amplitudes and their esd's after correction for scan speed, background, Lorentz, and polarization effects. An empirical absorption correction, based on the azimuthal scan data, was applied to the data. Crystallographic computations were carried out on a Microvax III computer using the NRCC-SDP-VAX structure determination package. ${ }^{37}$

A suitable single crystal of $\mathbf{3}$ was mounted on the top of a glass fiber with glue. Initial lattice parameters were determined from 24 accurately centered reflections with $2 \theta$ values in the range from 18.86 to $30.22^{\circ}$. Cell constants and other pertinent data were collected and are recorded in Table 1 . Reflection data were collected using the $\theta / 2 \theta$ scan method. The final scan speed for each reflection was determined from the net intensity gathered during an initial prescan and ranged from 2.06 to $8.24^{\circ} \mathrm{min}^{-1}$. The $\theta$ scan angle was determined for each reflection according to the expression $0.85 \pm 0.35 \tan \theta$. Three check reflections were measured every $30 \mathrm{~min}$ throughout the data collection and showed no apparent decay. The merging of equivalent and duplicate reflections gave a total of 6742 unique measured data, of which 4777 reflections with $I>2 \sigma(I)$ were considered observed. The first step of the structure solution used the heavy-atom method (Patterson synthesis), which revealed the positions of the metal atoms. The remaining atoms were found in a series of alternating difference Fourier maps and leastsquares refinements. The quantity minimized by the least-squares program was $w\left(\left|F_{\mathrm{o}}\right|-\left|F_{\mathrm{c}}\right|\right)^{2}$, where $w$ is the weight of a given operation. The analytical forms of the scattering factor tables for the neutral atoms were used. ${ }^{38,39}$ The non-hydrogen atoms were refined anisotropically. Hydrogen atoms were included in the structure factor calculations in their expected positions on the basis of idealized bonding geometry but were not refined in least squares. All hydrogens were assigned isotropic thermal parameters $1-2 \AA^{2}$ larger than the equivalent $B_{\text {iso }}$ values of the atoms to which they were bonded. The final residuals of this refinement were $R=0.040$ and $R_{\mathrm{w}}=0.042$.

The procedures for $6,9 \mathbf{a}$, and $11 \mathrm{~d}$ were similar to those for $\mathbf{3}$. The final residuals of the refinements were $R=0.034$ and $R_{\mathrm{w}}=0.037$ for 6, $R=0.047$ and $R_{\mathrm{w}}=0.044$ for $9 \mathrm{a}$, and $R=0.038$ and $R_{\mathrm{w}}=0.041$ for 11d.

Acknowledgment. We thank the National Science Council of Taiwan, Republic of China, for support.

Supporting Information Available: X-ray crystallographic files, in CIF format, for the structures of complexes $\mathbf{3}, \mathbf{6}, \mathbf{9 a}$, and $\mathbf{1 1 d} \cdot \mathrm{CHCl}_{3}$. This material is available free of charge via the Internet at http:// pubs.acs.org.

IC9904438

(37) Gabe, E. J.; Lee, F. L.; Lepage, Y. In Crystallographic Computing 3; Sheldrick, G. M., Kruger, C., Goddard, R., Eds.; Clarendon Press: Oxford, England, 1985; p 167.

(38) International Tables for X-ray Crystallography; Reidel: Dordrecht. Boston, 1974; Vol. IV.

(39) LePage, Y.; Gabe, E. J. Appl. Crystallogr. 1990, 23, 406. 